\title{
Erythroxylum (Erythroxylaceae) na Mata Atlântica da Bahia, Brasil
}

\author{
Erythroxylum (Erythroxylaceae) in the Atlantic Forest of Bahia, Brazil
}

\author{
Thiago Felipe de Araújo ${ }^{1,4}$, Pedro Fiaschi ${ }^{2}$ \& André M. Amorim ${ }^{3}$
}

\begin{abstract}
Resumo
Neste trabalho é apresentado o levantamento florístico de Erythroxylum na Mata Atlântica do estado da Bahia. Todas as informações sobre as espécies foram obtidas através de análise de exsicatas depositadas nos herbários ALCB, CEPEC, HRB, HUEFS, HUESC, MBM, R, RB, SP, SPF e consultas virtuais aos herbários BR, F, NY e K. Foram realizadas expedições em campo, priorizando regiões com poucas coletas, registros de espécies raras e suspeitas de novidades taxonômicas. Foram registradas 28 espécies, sendo E. ectinocalyx um novo registro para a Bahia e E. compressum, E. distortum, E. leal-costae, E. mattos-silvae, E. membranaceum e E. petrae-caballi constantes na lista de espécies da flora brasileira ameaçadas de extinção. São apresentadas descrições, ilustrações, chave de identificação e comentários para todas as espécies estudadas.

Palavras-chave: flora, taxonomia, Malpighiales.
\end{abstract}

\begin{abstract}
A floristic treatment of Erythroxylum species from the Atlantic Forest of Bahia State is presented. We analyzed specimens from the following Brazilian herbaria: ALCB, CEPEC, HRB, HUEFS, HUESC, MBM, R, RB, SP, $\mathrm{SPF}$, as well as images of specimens from a few virtual herbaria: BR, F, K, and NY. Field work was carried out in the studied area, to visit areas with few collections, record rare species, and find possibly undescribed taxa. Twenty eight species of Erythroxylum were recorded, among which E. ectinocalyx represents a new record for the state and E. compressum, E. distortum, E. leal-costae, E. mattos-silvae, E. membranaceum and E. petrae-caballi are threatened. We present descriptions, illustrations, identification keys and comments for all studied species.
\end{abstract}

Key words: flora, taxonomy, Malpighialess.

\section{Introdução}

Erythroxylaceae Kunth é uma família de distribuição tropical, constituída pelos gêneros Aneulophus Benth., Nectaropetalum Engl., Pinacopodium Exell \& Mendonça e Erythroxylum P. Browne, sendo os três primeiros restritos ao continente africano e o último presente em toda a zona tropical (Heywood et al. 2007). A família já foi incluída na ordem Linales por Cronquist (1981), porém recentes estudos moleculares e morfológicos apontaram o táxon como grupo irmão de Rhizophoraceae (Wurdack \& Davis 2009; Xi et al. 2012), assegurando sua posição dentro da ordem Malpighiales.

Erythroxylum é o maior gênero da família e comporta cerca de 230 espécies, que ocorrem em sua maioria na América do Sul (Daly 2004). O Brasil, com cerca de 114 espécies, é apontado como um importante centro de diversidade e endemismo do grupo (Plowman \& Hensold 2004), especialmente a Região Nordeste, que abriga 71 espécies (Loiola 2013), boa parte destas, descritas nos últimos trinta anos (Costa-Lima \& Alves 2013; Loiola \& Sales 2008, 2012; Plowman 1983, 1986 e 1987). Dentre os estados brasileiros, a Bahia é o que apresenta maior número de espécies de Erythroxylum (ca. de 50), distribuídas principalmente na Mata Atlântica (Plowman 1987). Essa alta diversidade de Erythroxylum na Mata Atlântica da Bahia é acompanhada por uma destacada taxa de endemismo, já que das 13 espécies apontadas como endêmicas da Bahia por Loiola (2013), apenas $E$. longisetulosum não ocorre neste bioma.

\footnotetext{
${ }^{1}$ Universidade Estadual de Feira de Santana, Depto. Ciências Biológicas, Av. Transnordestina s/n, Novo Horizonte, 44036-900, Feira de Santana, BA, Brasil.

${ }^{2}$ Universidade Federal de Santa Catarina, Centro de Ciências Biológicas, Depto. Botânica, Campus Universitário, Trindade, 88040-900, Florianópolis, SC, Brasil.

${ }^{3}$ Universidade Estadual de Santa Cruz, Depto. Ciências Biológicas, Rod. Ilhéus-Itabuna km 16, 45600-970, Ilhéus, BA, Brasil.

${ }^{4}$ Autor para correspondência: t.araujo.bio@gmail.com
} 
A presença de catafilos, estípulas intrapeciolares, flores diminutas, heterostílicas com tubo estaminal curto e frutos do tipo drupa permitem o reconhecimento do gênero. Porém, a complexidade morfológica de alguns caracteres, o elevado número de espécies simpátricas, a falta de chaves taxonômicas e de trabalhos que reúnam informações, especialmente sobre as espécies descritas nos últimos anos, tornam sua distinção infragenérica uma tarefa difícil. Diante desta problemática, objetivou-se neste trabalho contribuir para o conhecimento sobre a riqueza e distribuição de Eryhtroxylum na Mata Atlântica da Bahia, apontar os caracteres úteis para a identificação das espécies e fornecer descrições morfológicas, ilustrações e uma chave taxonômica contemplando todas as espécies encontradas.

\section{Material e Métodos}

Foram efetuadas análises de exsicatas depositadas nos herbários ALCB, CEPEC, HRB, HUEFS, HUESC, MBM, R, RB, SP, SPF e consultas virtuais aos herbários BR, F, K e NY (siglas seguem Thiers, continuamente atualizado). Estas informações foram complementadas por observações feitas em campo, priorizando regiões com poucas coletas, com registros de espécies raras ou possíveis novidades taxonômicas. A área de estudo considerada foi a extensão da Mata Atlântica no estado da Bahia, como delimitada pelo Mapa de Biomas do IBGE (2004) (Fig. 1). Quanto às fitofisionomias, foram adotados os limites propostos por Thomas \& Barbosa (2008) que consideraram os seguintes tipos vegetacionais na Mata Atlântica da Bahia: restinga (arbustiva e arbórea), tabuleiro (floresta de tabuleiro, mussununga e campo nativo), floresta ombrófila densa (montana, submontana e de terras baixas), floresta estacional semidecidual (submontana e de terras baixas) e floresta estacional decidual (submontana e de terras baixas). A compilação das informações sobre a distribuição geográfica das espécies fora da área de estudo foi baseada em literatura (Loiola 2013, 2001) e eventuais categorias infra-específicas não foram adotadas neste trabalho.

A terminologia morfológica foi baseada em Radford et al. (1974) e para a definição de termos como catafilo, sétula, lígula, flores brevistilas e flores longistilas seguiu-se Schulz (1907) e Loiola (2001). Todas as flores ilustradas tiveram a corola total ou parcialmente removida.

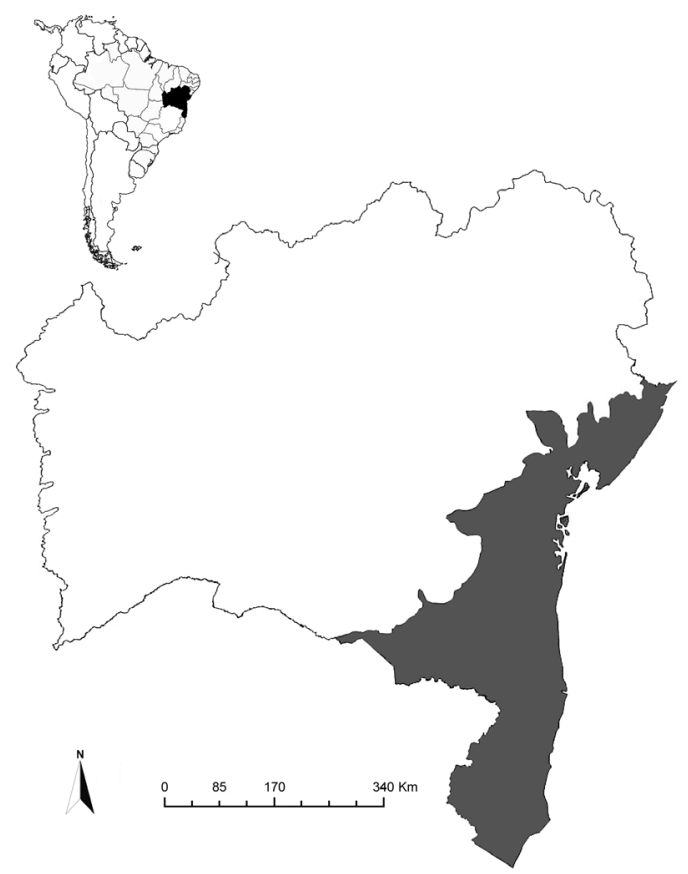

Figura 1 - Limites do Bioma Mata Atlântica no estado da Bahia adaptado de IBGE (2004)

Figure 1 - Limits of the Atlantic Forest biome in Bahia state, adapted from IBGE (2004).

\section{Chave para as espécies de Erythroxylum da Mata Atlântica na Bahia, Brasil}

1. Estípulas estriadas (às vezes com estrias evidentes apenas nas estípulas jovens ou em sua face interna, E. squamatum).

2. Estípulas iguais ou maiores que $5 \mathrm{~mm}$ compr.

3. Estípulas com margem fimbriada .

11. Erythroxylum hamigerum

3'. Estípula com margem inteira (raro erosa, E. columbinum).

4. Pecíolo 6-20 $\mathrm{mm}$ compr.

18. Erythroxylum nobile

4'. Pecíolo menor que $6 \mathrm{~mm}$ compr.

5. Catafilos do mesmo tamanho que as estípulas.

6. Arbusto monopodial; lâmina foliar $22-37 \mathrm{~cm}$ compr. 
6'. Arvoreta ramificada; lâmina foliar 6,5-16 mm compr.

3. Erythroxylum citrifolium

5'. Catafilos maiores que as estípulas.

7. Estípulas 2-setuladas; lâmina foliar com margem ondulada

22. Erythroxylum polygonoides

7'. Estípulas 3-setuladas; lâmina foliar com margem plana ou levemente revoluta.

8. Estípulas 5-6,5 mm compr.; lâmina foliar com margem levemente revoluta

4. Erythroxylum columbinum

8'. Estípulas 10-25 mm compr.; lâmina foliar com margem plana

17. Erythroxylum mucronatum

2'. Estípulas menores que $5 \mathrm{~mm}$ compr.

9. Estípulas com margem fimbriada (pelo menos quando jovens) ou erosa.

10. Pedicelo $2-3 \mathrm{~mm}$ compr.; bractéolas 3

16. Erythroxylum mikanii

10'. Pedicelo 7-11 mm compr., bractéolas 2

21. Erythroxylum petrae-caballi

9'. Estípulas com margem inteira.

11. Lâmina foliar com base assimétrica

5. Erythroxylum compressum

11'. Lâmina foliar com base simétrica.

12. Lâmina foliar com face abaxial brilhante

1. Erythroxylum andrei

12'. Lâmina foliar com face abaxial opaca.

13. Lobos do cálice do mesmo tamanho ou maiores que o tubo estaminal.

14. Estípulas com ápice arredondado; lâmina foliar às vezes com margem levemente revoluta

27. Erythroxylum suberosum

14'. Estípulas com ápice agudo; lâmina foliar nunca com margem revoluta.

15. Bractéolas 3; drupa oval com endocarpo liso

15. Erythroxylum membranaceum

15'. Bractéolas 2; drupa oblonga com endocarpo 6-sulcado.

16. Ramos com lenticelas numerosas; pecíolos até $3 \mathrm{~mm}$ compr.; lâmina foliar com ápice agudo ou arredondado, pedicelos até 7 mm compr. 20. Erythroxylum passerinum

16'. Ramos com lenticelas pouco numerosas; pecíolos 3-7 mm compr.; lâmina foliar com ápice acuminado ou cuspidado; pedicelos ca. $10 \mathrm{~mm}$ compr. .... 26. Erythroxylum squamatum

13'. Lobos do cálice menores que o tubo estaminal

17. Catafilos menores que as estípulas; estípulas com ápice arredondado; pecíolo 6-15 mm compr.; lâmina foliar 10-25 cm compr.

14. Erythroxylum mattos-silvae

17'. Catafilos do mesmo tamanho que as estípulas; estípulas com ápice agudo; pecíolo 1-5 mm compr.; lâmina foliar 2-7,5 cm compr.

18. Lâmina foliar coriácea, com ápice arredondado ou retuso; bractéolas não estriadas; pedicelo $1-1,5 \mathrm{~mm}$ compr.; drupa com endocarpo 3-sulcado

12. Erythroxylum leal-costae

18'. Lâmina foliar cartácea ou membranácea com ápice agudo ou atenuado, bractéolas estriadas, pedicelo $2-5 \mathrm{~mm}$ compr.; drupa com endocarpo liso.

19. Bractéolas 6 ou mais, triangulares com margem inteira; pétala 1-2 mm compr., lígula ca. 0,4 mm compr., flores com estiletes conatos 28. Erythroxylum tenue

19'. Bractéolas 3, ovais com margem erosa; pétala de 3-4 mm compr., lígula ca. $1 \mathrm{~mm}$ compr., flores com estiletes livres ....

1'. Estípulas não estriadas. 7. Erythroxylum distortum

20. Estípulas com margem fimbriada 9. Erythroxylum flaccidum

20'. Estípulas com margem inteira. 
21. Estípulas com ápice agudo.

22. Drupa falcada, endocarpo 3-sulcado, três lóculos desenvolvidos.

23. Ramo esbranquiçado, lenticelas numerosas; lâmina foliar com face abaxial opaca e ápice acuminado 10. Erythroxylum grandifolium

23'. Ramo castanho escuro, lenticelas pouco numerosas; lâmina foliar com face abaxial brilhante e ápice arredondado 25. Erythroxylum splendidum

22'. Drupa oblonga, oval ou largamente oval, endocarpo liso ou 6-sulcado, um lóculo desenvolvido.

24. Estípulas 8-20 mm compr.; drupa com endocarpo 6-sulcado ........ 13. Erythroxylum martii

24'. Estípulas 1-2 mm compr.; drupa com endocarpo liso.

25. Lobo do cálice ca. $2 \mathrm{~mm} \times 1 \mathrm{~mm}$

6. Erythroxylum cuspidifolium

$25^{\prime}$. Lobo do cálice ca. $4 \mathrm{~mm} \times 2 \mathrm{~mm}$

8. Erythroxylum ectinocalyx

21'. Estípulas com ápice arredondado.

26. Pecíolo 6-15 mm compr.; lobo do cálice menor que o tubo estaminal

23. Erythroxylum pulchrum

26'. Pecíolo 2-4 mm compr.; lobo do cálice maior que o tubo estaminal.

27. Lenticelas numerosas; pedicelo 1-2 mm compr.; bractéolas 3, lanceoladas

24. Erythroxylum santosii

27'. Lenticelas pouco numerosas; pedicelo $4-10 \mathrm{~mm}$ compr.; bractéolas 2, oblongas

19. Erythroxylum ochranthum

\section{Resultados e Discussão}

Foram encontradas 28 espécies de Erythroxylum na Mata Atlântica da Bahia, os caracteres mais úteis na separação das espécies foram o tamanho, formato e ornamentação (estriada ou não estriada) das estípulas, o comprimento do pecíolo e do pedicelo, o tamanho dos lobos do cálice em relação ao tubo estaminal e o grau de fusão dos estiletes (livres ou conatos por $1 / 3,1 / 2$ ou $2 / 3$ do compr.). Um novo registro (E. ectinocalyx) foi indicado para o estado e pela primeira vez $E$. membranaceum e E. petrae-caballi tiveram suas flores longistilas descritas.

1. Erythroxylum andrei Plowman, Fieldiana, Bot. 19: 2.1987.

Fig. 2a-b

Arbusto 2-6 m alt., densamente ramificado, ramo marrom ou acinzentado, porção jovem achatada; lenticelas numerosas, distribuídas por todo o ramo. Catafilos do mesmo tamanho que as estípulas, pouco numerosos, esparsos, às vezes adensados na base dos ramos jovens, enegrecidos quando herborizados. Estípulas persistentes, 1-2 $\mathrm{mm}$ compr., triangulares, estriadas, margem inteira, ápice arredondado, curtamente 3-setulado, sétulas enegrecidas; pecíolo 1,5-3 $\mathrm{mm}$ compr. Lâmina foliar 3-9 × 2-5,5 cm, cartácea a coriácea, elíptica a largamente elíptica, oval ou oboval, face adaxial verde escura, opaca, abaxial verde clara, brilhante, base cuneada a arredondada, simétrica, margem plana, ápice arredondado ou retuso. Fascículo 1-5 flores, bractéolas 3 , ca. $0.8 \mathrm{~mm}$ compr., ovais, não estriadas, margem inteira. Flor com pedicelo de 3-6 mm compr; cálice verde, lobos ca. 0,5 ×0,8 mm, triangulares a largamente triangulares, menores que o tubo estaminal; pétalas esbranquiçadas ou amareladas, 2,5-3 × 1-1,5 mm, elípticas; tubo estaminal 1-1,5 mm compr., margem inteira, ovário ca. $1 \mathrm{~mm}$ compr., oboval. Flor brevistila: estames ca. $3 \mathrm{~mm}$ compr., estiletes $1-1,5 \mathrm{~mm}$ compr., livres. Flor longistila: estames opositissépalos ca. $0,8 \mathrm{~mm}$ compr., alternissépalos ca. 1,2 mm compr; estiletes ca. 1,8 mm compr., livres. Drupa 7-9 × 3-4 mm, oblonga a elíptica, endocarpo liso.

Erythroxylum andrei apresenta distribuição restrita à Região Nordeste do Brasil, nos estados de Alagoas, Bahia e Sergipe (Loiola 2013). Na Bahia a espécie ocorre em restinga arbustiva e/ou arbórea, campo nativo e mussununga. Pertence a Erythroxylum sect. Rhabdophyllum O.E. Schulz, assemelhando-se a outras espécies da seção como $E$. distortum, E. leal-costae, E. mikanii e E. passerinum. Porém, E. andrei pode ser distinta das demais pelas estípulas com o ápice arredondado e sétulas enegrecidas, lâminas foliares com a face abaxial brilhante e tubo estaminal com a margem inteira.

Material selecionado: BRASIL. BAHIA: Cairu, $13^{\circ} 29^{\prime} \mathrm{S}, 39^{\circ} 02^{\prime}$ 'W, 12.IV.2003, fr., M.L. Guedes \& D. Rigueira 10242 (ALCB, CEPEC). Camaçari, 7.II.1987, fl., G.C.P. Pinto 1687 (HUEFS). Ilhéus, Olivença, 12.XI.1970, fl., T.S. Santos 1287 (CEPEC). Itacaré, Campo Cheiroso, 3.IV.2013, est., T. Araújo \& M. Nogueira 191 (CEPEC). Jandaira, 11³6’46”S, 

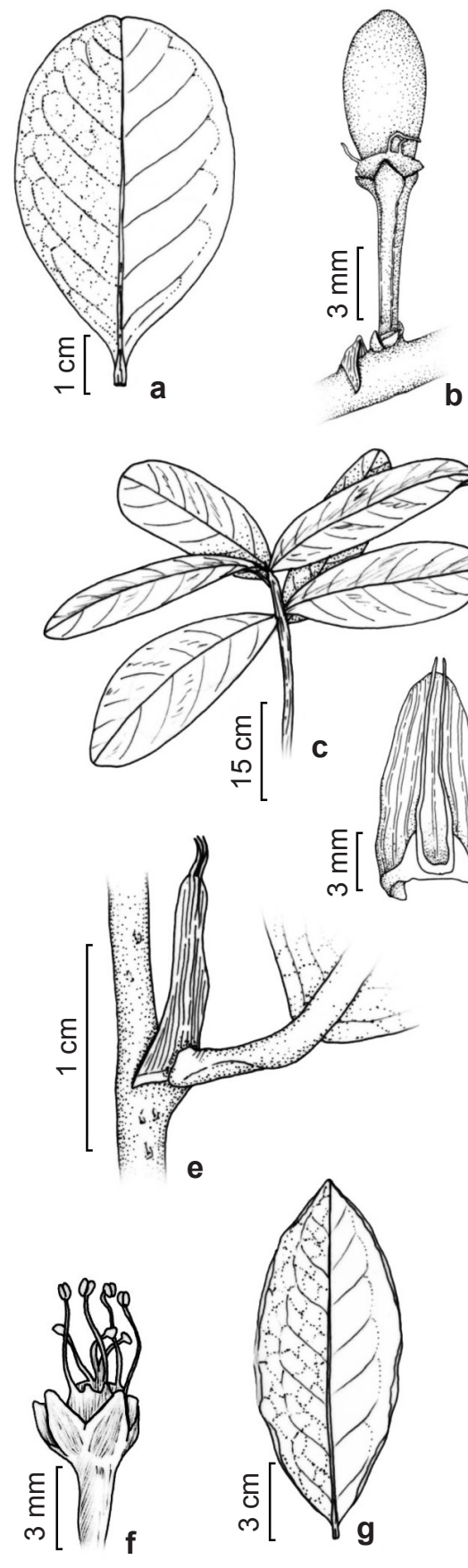
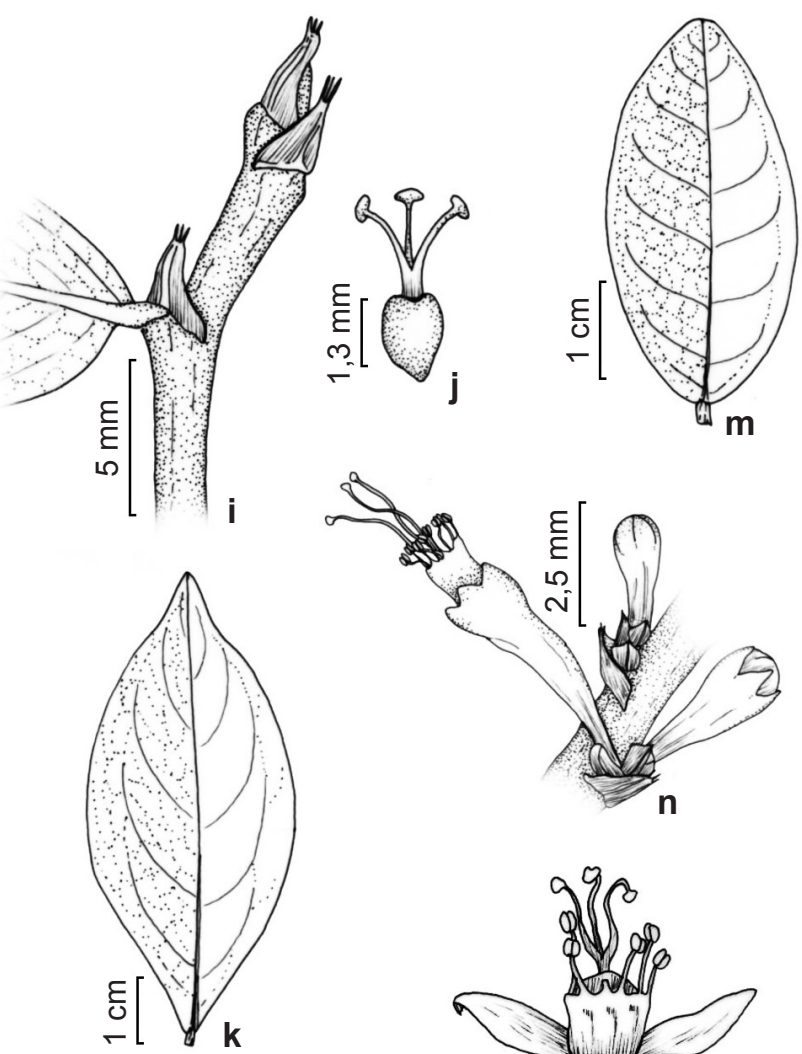

d
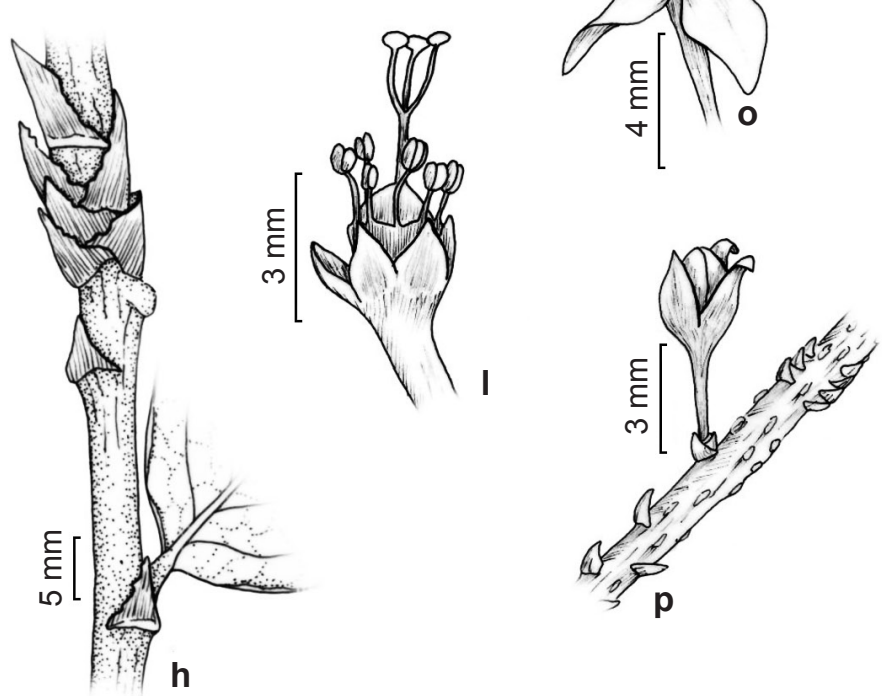

Figura 2 -a-b. E. andrei -a. lâmina foliar; b. drupa. c-d. E. bradeanum - c. hábito; d. estípula. e-f. E. citrifolium - e. ramo com estípula e pecíolo; f. flor brevistila. g-h. E. columbinum - g. lâmina foliar; h. ramo com catafilos, estípula e pecíolo. i-j. E. compressum - i. ramo com catafilos, estípula e pecíolo; j. gineceu. k-1. E. cuspidifolium - k. lâmina foliar; 1. flor longistila. m-n. E. distortum - m. lâmina foliar; n. ramo com catafilos, botões florais e flor longistila. o-p. E. ectinocalyx - o. flor longistila; p. ramo com catafilos e botão floral.

Figure 2 - a-b. E. andrei -a. leaf; b. drupe. c-d. E. bradeanum - c. habit; d. stipule. e-f. E. citrifolium -e. branch with stipule and petiole; f. short-styled flower. g-h. E. columbinum - g. leaf; h. branch with cataphyll, stipule and petiole. i-j. E. compressum - i. branch with cataphyll, stipule and petiole; j. gyneceum. k-1. E. cuspidifolium - k. leaf; 1. long-styled flower. m-n. E. distortum - m. leaf; n. branch with cataphylls, flower buds and long-styled flower. o-p. E. ectinocalyx - o. long-styled flower; p. Branch with cataphylls and flower bud. 
37³6'46”W, 5.XII.2011, est., E. Matos \& G. Vidal 2684 (HUEFS). Maraú, BR 030, 26.II.1980, fl. e fr., A.M. de Carvalho et al. 198 (CEPEC, RB). Porto Seguro, Arraial d'Ajuda para Trancoso, 20.IV.1982, fr., A.M. de Carvalho et al. 1249 (CEPEC, HRB, RB).

2. Erythroxylum bradeanum O.E.Schulz, Notizbl. Bot. Gart. Berlin-Dahlem 11: 722. 1933.

Fig. 2c-d

Arbusto 1-1,2 m alt., monopodial, ramo castanho escuro; lenticelas pouco numerosas, distribuídas na parte apical o ramo. Catafilos do mesmo tamanho que as estípulas, pouco numerosos a numerosos, presentes principalmente na porção apical do ramo, congestos. Estípulas decíduas, 15-20 mm compr., triangulares, estriadas, margem inteira, ápice agudo ou obtuso, 2-setulado; pecíolo 2-3 mm compr. Lâmina foliar 22-37 × 10,5-15 cm, membranácea a coriácea, elíptica ou obtrulada, face adaxial verde escura brilhante, abaxial verde clara, opaca, base cuneada, margem plana, ápice agudo. Fascículo 1-9 flores, dispostas de forma espiralada pelo ramo; bractéolas 3, 2-3 mm compr., ovais, estriadas, margem inteira. Flor com pedicelo de 2-4 mm compr.; cálice verde, lobos 1,4-2 × 0.8-1 mm compr., triangulares, maiores que o tubo estaminal; pétalas de coloração creme, ca. $4 \times 1,5 \mathrm{~mm}$, oblonga; tubo estaminal 1-1,5 mm compr., margem crenulada, ovário ca. $1 \mathrm{~mm}$ compr., oblongo. Flor brevistila: não observada. Flor longistila: estames opositissépalos ca. $0,5 \mathrm{~mm}$ compr., alternissépalos ca. 0,8 mm compr.; estiletes ca. $2 \mathrm{~mm}$ compr., conatos ca. $1 / 2$ compr. Drupa 10-14 × 3-4,5 mm compr., oblonga, endocarpo liso.

A distribuição dessa espécie é conhecida apenas para Rio de Janeiro (Schulz 1933) e Bahia, neste último até então por um único registro (Amorim et al. 2008). No presente trabalho são citadas três novas coletas de $E$. bradeanum para o estado. Schulz (1933) não fez referência a qual seção E. bradeanum pertencia, mas considerando as estípulas estriadas e os lobos do cálice triangulares, sugerimos sua inclusão em Erythroxylum sect. Rhabdophyllum. Pode ser reconhecida pelo hábito arbustivo monopodial, flores dispostas em espiral no caule, lâminas foliares com 22-37 cm compr., estípulas estriadas e flores longistilas com estiletes conatos.

Material selecionado: BRASIL. BAHIA: Arataca, $15^{\circ} 10^{\prime} \mathrm{S}$, 39²0’W, 20.VI.2012, fr., T. Araújo et al. 70 (CEPEC). Camacã, 24.V.1971, fr., T.S. Santos 1692 (CEPEC). Mascote, 15.X.1981, fl., L.A. Mattos Silva et al. 2604 (CEPEC). Una, 10.V.1993, fl., W. Thomas et al. 9856 (CEPEC).
3. Erythroxylum citrifolium A.St-Hil., Fl. bras. merid. 2: 94 . 1829.

Fig. 2e-f

Arvoreta 5-10 m alt., ramo castanho escuro; lenticelas numerosas, distribuídas por todo o ramo. Catafilos do mesmo tamanho que as estípulas, numerosos, distribuídos ao longo do ramo ou agrupados na porção jovem dos ramos, esparsos; Estípulas frequentemente decíduas, 8-18 mm compr., cartáceas, triangulares, estriadas, margem inteira, ápice arredondado, 3-setulado; pecíolo 4-6 mm compr. Lâmina foliar 6,5-16 × 2-5,5 cm, membranácea, oblonga a elíptica, face adaxial verde escura e brilhante, abaxial verde clara, opaca, frequentemente com galhas, base cuneada, margem plana, ápice agudo a acuminado. Fascículo 2-19 flores, bractéolas 3, 2-2,5 mm compr., triangulares, estriadas, margem inteira. Flor com pedicelo de 3-5,5 mm compr.; cálice verde, lobos 1-1,4 × 0,8-1,3 mm, triangulares a ovais, pouco maiores que o tubo estaminal; pétalas esbranquiçadas a amareladas, ca. $3 \times 1 \mathrm{~mm}$, oblongas; tubo estaminal ca. 1,5 mm compr., margem denticulada, ovário ca. $1 \mathrm{~mm}$ compr., oblongo. Flor brevistila: estames 2,5-3 mm compr., estiletes 1,5-2 mm compr., livres. Flor longistila: estames opositissépalos ca. $1 \mathrm{~mm}$ compr., alternissépalos ca. 1,5 mm compr.; estiletes ca. $3 \mathrm{~mm}$ compr., livres. Drupa 10-15 $\times$ 3-5 mm, elíptica, endocarpo liso.

Espécie amplamente distribuída pela América Central e do Sul, ocorrendo desde o México até o sul do Brasil (Loiola 2001, 2013; Plowman \& Hensold 2004). Na Bahia foi encontrada em restinga arbustiva e arbórea, floresta ombrófila de terras baixas e submontana e em floresta estacional semidecidual. Pertence a Erythroxylum sect. Rhabdophyllum e assemelha-se a E. mucronatum, porém os são catafilos do mesmo tamanho que as estípulas (vs. catafilos maiores que as estípulas em E. mucronatum) e as estípulas possuem ápice arredondado (vs. ápice agudo em E. mucronatum). Pode ser diferenciada das demais espécies da área de estudo pelas estípulas estriadas com 8-18 mm compr. e tubo estaminal com margem denticulada menor que os lobos do cálice.

Material selecionado: BRASIL. BAHIA; Amargosa, 13¹0'20"'S, 3909'34'W, 26.I.2007, fl., D. Cardoso et al. 1607 (CEPEC, HUEFS). Amélia Rodrigues, 4.V.2000, fr., F. França et al. 1230 (HUEFS). Arataca, $15^{\circ} 11$ '43”'S, 39²3'13"W, 11.IX.2011, fl., R. Perdiz et al. 919 (CEPEC). Cairu, 1985, fl., L.A. Mattos Silva \& T.S. Santos 1895 (CEPEC). Eunápolis, 14.IV.1967, fr., P. Lanna \& A. Castellanos 1336 (CEPEC). Guaratinga, 29.X.1979, fl., L.A. Mattos Silva \& H.S. Brito 642 (CEPEC). Porto 
Seguro, 16²5'09'S, 39¹2'8' 'W, 18.III.2010, fr., L. Daneu et al. 318 (CEPEC). Wenceslau Guimarães, 1.IV.1993, fl., S.C. de Sant'Ana et al. 306 (CEPEC).

4. Erythroxylum columbinum Mart., Abh. Math.Phys. Cl. Königl. Bayer. Akad. Wiss. 3(2): 379. 1843.

Fig. $2 \mathrm{~g}-\mathrm{h}$

Arbusto ou arvoreta 4-6 $\mathrm{m}$ alt., ramo castanho claro, porção jovem achatada; lenticelas numerosas, distribuídas por todo o ramo. Catafilos maiores que as estípulas, numerosos, agrupados em várias regiões do ramo, congestos; Estípulas persistentes, 5-6,5 $\mathrm{mm}$ compr., triangulares, estriadas, margem frequentemente erosa, ápice agudo, 3-setulado; pecíolo 2-4 mm compr. Lâmina foliar 7-13,5 × 2-6 cm, coriácea, elíptica, face adaxial verde escura, brilhante, abaxial verde clara, dourada quando herborizada, opaca, base cuneada, margem levemente revoluta, ápice agudo. Fascículo 1-13 flores, bractéolas 2, 1,5-2 mm compr., triangulares, inconspicuamente estriadas, margem inteira a erosa. Flor com pedicelo de 10-14 mm compr., cálice verde, lobos $1-1,5 \times$ ca. $1 \mathrm{~mm}$, triangulares, maiores que o tubo estaminal; pétalas esbranquiçadas, $3-5 \times 2-2,5 \mathrm{~mm}$, oblongas; tubo estaminal ca. $1 \mathrm{~mm}$ compr., margem crenulada, ovário ca. 1,5 mm compr., oblongo. Flor brevistila: estames 3-4 mm compr., estiletes 1,5-2 mm compr., livres. Flor longistila: estames opositissépalos ca. $1 \mathrm{~mm}$ compr., alternissépalos ca. 1,8 mm compr.; estiletes ca. $3 \mathrm{~mm}$ compr., livres. Drupa 12-15 $\times$ 4-6 mm, oval ou oblonga, endocarpo liso.

A distribuição geográfica de Erythroxylum columbinum limita-se à Bahia, Pernambuco e Sergipe (Loiola, 2013). Na Bahia a espécie ocorre no interior de floresta ombrófila de terras baixas ou, raramente, em floresta estacional semidecidual. Pertence a Erythroxylum sect. Rhabdophyllum e pode ser reconhecida pelos catafilos maiores que as estípulas, lâmina foliar com margem levemente revoluta e face abaxial dourada após herborização. Os pedicelos alongados e o lobo do cálice maior que o tubo estaminal também auxiliam no seu reconhecimento.

Material selecionado: BRASIL. BAHIA: Arataca, $15^{\circ} 10^{\prime} 27^{\prime}$ 'S, 39²0'22”'W, 17.XII.2005, fr., J.G. Jardim et al. 4832 (CEPEC). Aurelino Leal, $14^{\circ} 20^{\prime} \mathrm{S}, 39^{\circ} 23^{\prime} \mathrm{W}$, 03.V.1992, fr., $W$. Thomas et al. 9103 (CEPEC). Barro Preto, 144' $13^{\prime}$ "S, 39 ${ }^{\circ} 12^{\prime} 10^{\prime \prime}$ W, 4.III.2011, fr., A.M. Amorim et al. 4879 (CEPEC). Cachoeira, 11.XI.1983, fl., G.C. Pereira Pinto et al. 365 (CEPEC, HRB). Ilhéus, 27.II,1985, est., T. Plowman et al. 13966 (CEPEC). Jussari, 23.VIII.1971, fl. e fr., T.S. Santos 1888 (CEPEC).
Santa Cruz Cabrália, 21.III.1978, est., S.A. Mori et al. 9809 (CEPEC). Una, 10.III.1986, bot., T.S. Santos et al. 4215 (CEPEC).

5. Erythroxylum compressum Peyr. in Mart., Eichler \& Urb., Fl. bras. 12(1): 163. 1878.

Fig. $2 \mathrm{i}-\mathrm{j}$

Arbusto ou arvoreta 1-3 m alt., ramo castanho acinzentado, porção jovem castanhoavermelhada, achatada; lenticelas pouco numerosas, distribuídas por todo o ramo. Catafilos do mesmo tamanho que as estípulas, pouco numerosos a numerosos, distribuídos por todo o ramo, esparsos; Estípulas persistentes, 2-3 $\mathrm{mm}$ compr., largamente triangulares, estriadas, margem inteira, ápice agudo, 3-setulado; pecíolo 1,5-2 mm compr. Lâmina foliar 11-18 × 4-7 cm, cartácea a membranácea, oblonga a elíptica, face adaxial verde escura, brilhante, abaxial verde clara, opaca, base arredondada, assimétrica, margem plana, ápice acuminado. Fascículo reduzido a 1 flor, bractéolas 2 , ca. $1 \mathrm{~mm}$ compr., triangulares, estriadas, margem inteira. Flor com pedicelo ca. $2 \mathrm{~mm}$ compr.; cálice verde, lobos $1-1,5 \times 0,5 \mathrm{~mm}$, triangulares, livres, maiores que o tubo estaminal; pétalas esbranquiçadas, ca. 3 $\times 1,5 \mathrm{~mm}$, oblongas; tubo estaminal ca. $2 \mathrm{~mm}$ compr., margem denticulada, ovário ca. $1,5 \mathrm{~mm}$ compr., oblongo. Flor brevistila: não observada. Flor longistila: estames opositissépalos ca. $1 \mathrm{~mm}$ compr., alternissépalos ca. 1,5 mm compr; estiletes 2-3 mm compr., conatos mais de $2 / 3$ do compr. Drupa 12-15 × 4-6 mm, elíptica, endocarpo liso.

Erythroxylum compressum é endêmico da Bahia (Loiola 2013) e ocorre em floresta ombrófila de terras baixas, submontanas, montanas ou restinga. Atualmente consta na lista de flora brasileira ameaçadas de extinção (Brasil 2008). Pertence a Erythroxylum sect. Rhabdophyllum e pode ser reconhecida pelo pecíolo curto $(1,5-2$ $\mathrm{mm}$ compr.) e base da lâmina foliar assimétrica, característica não encontrada nas outras espécies deste estudo.

Material selecionado: BRASIL. BAHIA: Camacã, $15^{\circ} 23^{\prime} 30^{\prime}$ 'S, 39॰33'55”'W, 23.I.2007, fl., R.A.X. Borges et al. 694 (CEPEC, RB). Camamu, 20.XII.2012, est., T. Araújo 90 (CEPEC). Itacaré, $14^{\circ} 25^{\prime} 5^{\prime}$ "S, 39 33' 5'W, 12.II.2011, fl., T. Araújo et al. 39 (CEPEC). Ituberá, 5.V.2000, fr., R.P. Oliveira 547 (HUEFS). Jussari, $15^{\circ} 10^{\prime}$ 'S, 39³5'W, 3.II.1998, fl., J.G. Jardim et al. 1488 (CEPEC). Porto Seguro, 19.IV.1982, fr., A.M. de Carvalho et al. 1195 (CEPEC). Una, 18.I.1998, fr., T.G. Bacelar et al. 17 (CEPEC, HUESC). 
6. Erythroxylum cuspidifolium Mart., Abh. Math.Phys. Cl. Königl. Bayer. Akad. Wiss. 3(2): 359. 1843.

Fig.2k-1

Arbusto ou arvoreta $1-12 \mathrm{~m}$ alt., ramo castanho ou acinzentado; lenticelas numerosas a pouco numerosas, concentradas na porção jovem dos ramos. Catafilos do mesmo tamanho que as estípulas, numerosos, adensados nos ramos floríferos e/ou nos ramos de crescimento curto; Estípulas persistentes, 1-2 mm compr., triangulares, não estriadas, margem inteira, ápice agudo, 2-3-setulado; pecíolo 2-4 mm compr. Lâmina foliar 4-8 × 1,5-3 cm, membranácea, elíptica a largamente elíptica, face adaxial verde escura, às vezes brilhante, face abaxial verde clara, opaca, base cuneada, margem plana, ápice cuspidado. Fascículo 3-22 flores, bractéolas 3 , ca. $1 \mathrm{~mm}$ compr., estreitamente lanceoladas, não estriadas, margem inteira a erosa. Flor com pedicelo de 4-7 mm compr., delgado; cálice verde, lobos ca. $2 \times 1 \mathrm{~mm}$, oval-elípticos, iguais ou pouco maiores que o tubo estaminal; pétalas de coloração creme, 3-4 × 1,5-2 mm, oblongoelípticas; tubo estaminal 1-1,5 mm compr., margem crenulada; ovário 1,5-2 mm compr. Flor brevistila não observada. Flor longistila estames opositissépalos ca. $1 \mathrm{~mm}$ compr., alternissépalos ca. 1,5 mm compr.; estiletes 2,5-3 mm compr., conatos $1 / 3$ a $1 / 2$ compr. Drupa 9-13 mm compr., oval, endocarpo 6-sulcado.

Erythroxylum cuspidifolium ocorre nas Regiões Sul, Sudeste e Nordeste (apenas Bahia) (Loiola 2013). Nesta última, foi registrada em floresta ombrófila densa de terras baixas, submontana e montana. Pertence a Erythroxylum sect. Microphyllum O.E. Schulz e assemelha-se a E. ectinocalyx (ver comentários nesta última). Pode ser reconhecido pela estípula não estriada, pecíolo com 2-4 mm compr., lâmina foliar com ápice cuspidado, lobos do cálice iguais ou pouco maiores que o tubo estaminal e drupas com endocarpo 6- sulcado.

Material selecionado: BRASIL. BAHIA: Arataca, 1510'27"S, 30²0'22"W, 18.XII.2006, fl., J.G. Jardim et al. 4878 (CEPEC). Barro Preto, 1446'13"S, 39॰12'10"'W, 7.II.2005, fr., A.M. Amorim et al 4834 (CEPEC). Elísio Medrado, 5.VI.1999, fl., F. França 2970 (HUEFS). Gandu, 23.X.1970, fl., T.S. Santos 1189 (CEPEC). Itacaré, $1^{\circ} 18^{\prime} \mathrm{S}, 39^{\circ} 2^{\prime} \mathrm{W}, 12 . \mathrm{IV} .1980$, est., T. Plowman et al. 10064 (CEPEC). Ituberá, 1340'S, $39^{\circ} 7^{\prime}$ W, 4.II.1983, est., T. Plowman \& A.M. de Carvalho 12810 (CEPEC).
7. Erythroxylum distortum Mart., Abh. Math.Phys. Cl. Königl. Bayer. Akad. Wiss. 3(2): 346. 1843.

Fig. $2 \mathrm{~m}-\mathrm{n}$

Arbusto 1-3 m alt., ramo castanho a castanho escuro, lenticelas pouco numerosas, distribuídas por todo o ramo. Catafilos do mesmo tamanho que as estípulas, numerosos, presentes principalmente na porção apical do ramo, congestos; Estípulas persistentes, 1,5-2 mm compr., triangulares, estriadas, margem inteira, ápice agudo, 3-setulado; pecíolo 2-3 $\mathrm{mm}$ compr. Lâmina foliar 4-6 $\times$ 2-3,5 cm, cartácea, elíptica, face adaxial verde escura brilhante, abaxial verde clara, opaca, base cuneada, margem plana, ápice agudo, frequentemente mucronado. Fascículo 1-2 flores, bractéolas 3, 1-1,5 mm compr., ovais, estriadas, margem levemente erosa. Flor com pedicelo de 4-5 mm compr.; cálice verde, lobos ca. 0,5 mm compr., ovais, conspicuamente menores que o tubo estaminal; pétalas de coloração creme, 3-4 $\times$ 1,5-2 mm, oblongas; tubo estaminal 1,5-2 mm compr., margem denticulada, ovário ca. $1 \mathrm{~mm}$ compr., oblongo. Flor brevistila: estames ca. 2 mm compr., estiletes ca. $1 \mathrm{~mm}$ compr., livres Flor longistila: estames opositissépalos ca. $0,5 \mathrm{~mm}$ compr., alternissépalos ca. $1 \mathrm{~mm}$ compr; estiletes ca. $3 \mathrm{~mm}$ compr., livres. Drupa 8-10 mm compr., oblonga, endocarpo liso.

Ocorre na Bahia, Pernambuco e Rio de Janeiro (Plowman e Hensold 2004; Loiola 2013), na Bahia foi encontrada em restinga, na porção sul do estado. Atualmente consta na lista de flora brasileira ameaçadas de extinção (Brasil 2008). Pertence a Erythroxylum sect. Rhabdophyllum e assemelha-se a E. membranaceum, E. mikanii e E. petrae-caballi (ver comentários em cada uma destas espécies).

Material selecionado: BRASIL. BAHIA: Ilhéus, 26.II.1985, est., T. Plowman et al. 13957 (CEPEC). Una, 13.V.1981, fr., A.M. de Carvalho et al. 683 (CEPEC). sem município, BR 101, trecho rio Jequitinhonha ao rio Pardo, 20.IV.1972, fl., T.S. Santos 2266 (CEPEC).

8. Erythroxylum ectinocalyx Mart. Abh. Math.Phys. Cl. Königl. Bayer. Akad. Wiss. 3(2): 355. 1843.

Fig.2o-p

Arbusto ou arvoreta 3-6 m alt., ramo castanhoclaro; lenticelas numerosas a pouco numerosas, concentradas na porção jovem dos ramos. Catafilos do mesmo tamanho que as estípulas, numerosos, congestos nos ramos floríferos e/ou nos ramos de crescimento curto; Estípulas persistentes, 1-2 mm 
compr., triangulares, não estriadas, margem inteira, ápice agudo, 2-3-setulado; pecíolo 3-5 mm compr. Lâmina foliar 7-9 × 2,5-4 cm, membranácea, elíptica a largamente elíptica, face adaxial verde escura, às vezes brilhante, face abaxial verde clara, opaca, base cuneada, margem plana, ápice cuspidado. Fascículo 4-13 flores, bractéolas 3, ca. 1 mm compr., lanceoladas, lisas, margem inteira. Flor com pedicelo de 3-5 mm compr., delgado; cálice ocre, lobos ca. $4 \times 2 \mathrm{~mm}$, largamente oval-elípticos, conspicuamente maiores que o tubo estaminal; pétalas de coloração creme, 3-4 × 1,5-2 mm, ovalelípticas; tubo estaminal 1,5-2 mm compr., sulcado, margem crenulada; ovário 1,5-2 mm compr. Flor brevistila: estames ca. $3 \mathrm{~mm}$ compr., estiletes ca. $1 \mathrm{~mm}$ compr., livres. Flor longistila: estames opositissépalos ca. $1 \mathrm{~mm}$ compr., alternissépalos ca. 1,5 mm compr; estiletes 2,5-3 mm compr., conatos $1 / 3$ compr. Drupa ca. $10 \times 4 \mathrm{~mm}$, oval a largamente oval, endocarpo 6-sulcado.

Até o momento Erythroxylum ectinocalyx havia sido registrada apenas na Região Sudeste, sendo este o primeiro registro para o Nordeste. Na Bahia, foi coletada em floresta ombrófila montana. Pertence a Erythroxylum sect. Microphyllum e se assemelha a E. cuspidifolium, da qual pode ser distinta pela coloração ocre do cálice (vs. verde em E. cuspidifolium) e lobos do cálice ca. $4 \times 2 \mathrm{~mm}$ (vs. ca. $2 \times 1 \mathrm{~mm}$ em E. cuspidifolium).

Material selecionado: BRASIL. BAHIA: Camacã, 15²3'30”'S, 39॰33'55'W, 29.X.2005, fl., A.M. Amorim et al. 5414 (CEPEC).

9. Erythroxylum flaccidum Salzm ex. Peyr.. in Mart., Eichler \& Urb., Fl. bras. 12(1): 141. 1878.

Fig. 3a-c

Arbusto ou arvoreta 1-10 m alt., castanho acinzentado, lenticelas pouco numerosas, distribuídas por todo o ramo. Catafilos do mesmo tamanho ou menores que as estípulas, pouco numerosos, presentes por todo o ramo, esparsos; Estípulas persistentes, 2-3 mm compr., triangulares, não estriadas, margem fimbriada, ápice arredondado, longamente 2-setulado; pecíolo 1,5-2 mm compr. Lâmina foliar 3-7 × 1-3,5 cm, membranácea, elíptica, face adaxial verde escura brilhante, abaxial verde clara, opaca, base cuneada, margem plana, ápice agudo. Fascículo reduzido a 1 flor, bractéolas 3 , ca. $1 \mathrm{~mm}$ compr., ovais, não estriadas, margem conspicuamente fimbriada. Flor com pedicelo de 4-7 mm compr.; cálice verde, lobos $1,5-2 \times 0,8-1,3 \mathrm{~mm}$, triangulares, maiores que o tubo estaminal; pétalas de coloração creme, 3-4 × 1,5-2 mm, oblongas; tubo estaminal ca. 1 mm compr., margem crenulada, ovário 1-1,3 mm compr., oblongo. Flor brevistila: estames ca. 3 mm compr., estiletes ca. 2 mm compr. livres Flor longistila: estames opositissépalos ca. 1,5 mm compr., alternissépalos ca. $2 \mathrm{~mm}$ compr; estiletes ca. $3 \mathrm{~mm}$ compr. livres. Drupa 9-15 mm compr., oblonga, endocarpo 6-sulcado.

Espécie amplamente distribuída pelas Regiões Centro-Oeste, Nordeste e Sudeste (Loiola 2013). Na Bahia foi encontrada em floresta ombrófila montana, submontana e de terras baixas, restinga arbustiva, arbórea e mussununga. Pertence a Erythroxylum sect. Archerythroxylum O.E. Schulz e pode ser reconhecida pelas estípulas não estriadas, longamente 2-setuladas, com margem fimbriada, lâmina foliar membranácea 3-7 × 1-3,5 cm e fascículos reduzidos a uma flor.

Material selecionado: BRASIL. BAHIA: Almadina, 1442'09”S, 39³6'14”'W, 7.VI.2012, fl., M.M. Coelho et al. 686 (CEPEC). Ibirapitanga, 28.III.2013, fr., $T$. Araújo \& M. Nogueira 181 (CEPEC, HUEFS). Itacaré, 12.IV.1980, est., T. Plowman et al. 10067 (CEPEC). Prado, 1705'09.3”S, 39¹9'19.2”W, IV.2013, est., T. Araújo \& M. Nogueira 202 (CEPEC). Santa Terezinha, 1251'13”'S, 39²8'36”'W, 26.III.2013, est., T. Araújo \& M. Nogueira 177 (CEPEC, HUEFS). Wenceslau Guimarães, 29.VIII.1991, fr., S. C. Sant'Ana et al 26 (CEPEC).

10. Erythroxylum grandifolium Peyr. in Mart., Eichler \& Urb., Fl. bras. 12(1): 161. 1878.

Fig. 3d-e

Arbusto ou arvoreta $1-4(-10) \mathrm{m}$ alt., ramo esbranquiçado, verde nas porções jovens, às vezes com ápice achatado, fissurado longitudinalmente; lenticelas numerosas, distribuídas por todo o ramo, recobertas por uma camada esbranquiçada nas porções mais velhas. Catafilos do mesmo tamanho que as estípulas, pouco numerosos, presentes em todo o ramo, esparsos; Estípulas persistentes, 2-3 $\mathrm{mm}$ compr., enegrecidas quando herborizadas, triangulares, não estriadas, margem inteira, ápice agudo, curtamente 2-setulado, sétulas enegrecidas; pecíolo ca. $1 \mathrm{~cm}$ compr. Lâmina foliar 7-25 $\times$ 3,5-9,2 cm, cartácea a membranácea, elíptica a largamente elíptica, face adaxial verde escura, brilhante, abaxial verde clara, opaca, base cuneada, margem plana, ápice acuminado, raramente cuspidado. Fascículo 1-3 flores, bractéolas 3, ca. $2 \mathrm{~mm}$ compr., oblongas, não estriadas, margem inteira. Flor com pedicelo de 2-3 mm compr.; cálice verde, lobos 3-4 × 2-2,8 mm, triangulares 

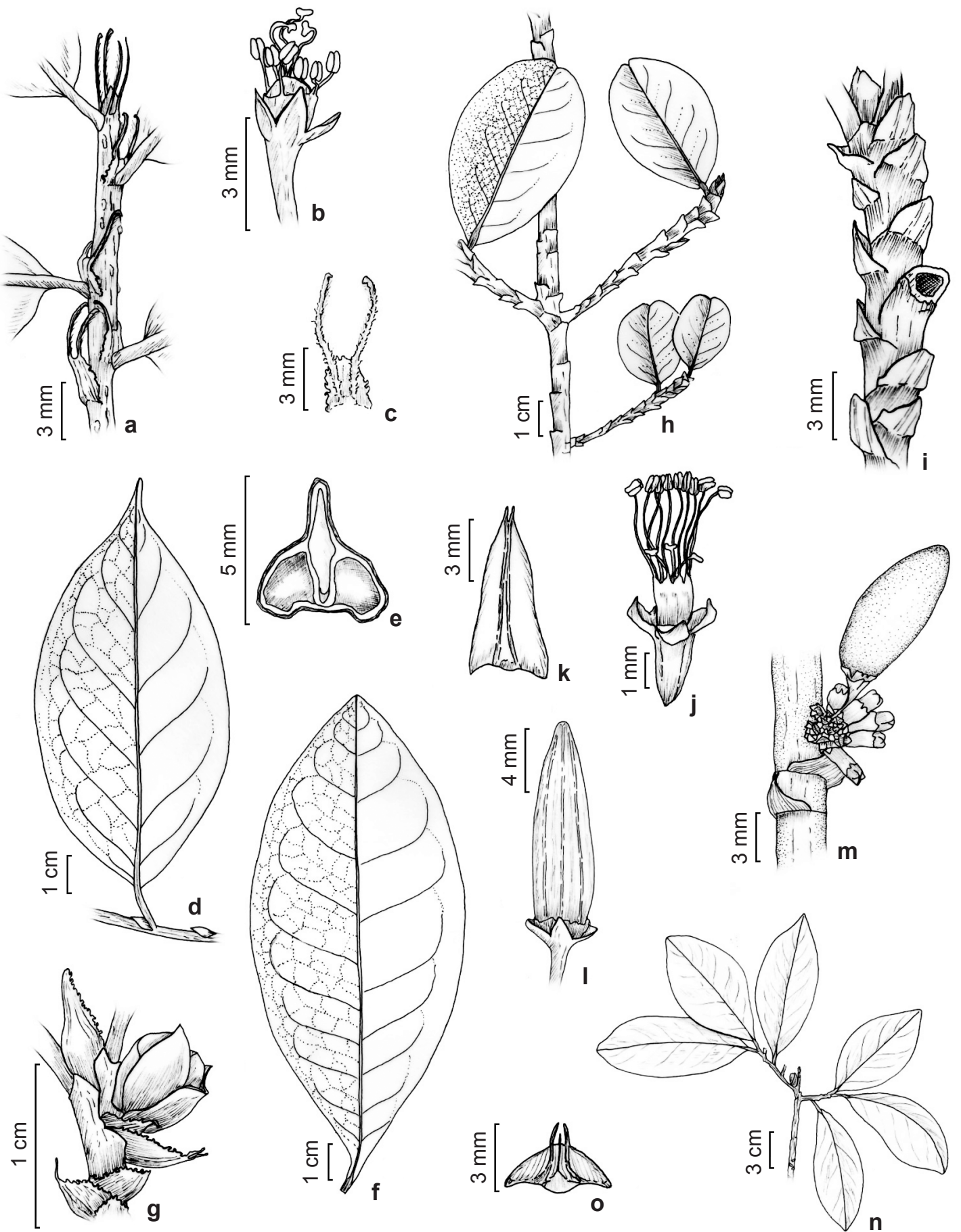

Figura 3 - a-c. E. flaccidum - a. ramo com catafilo e estípulas; b. flor longistila; c. estípula. d-e. E. grandifolium - d. ramo com catafilo, estípula e lâmina foliar; e. corte transversal da drupa. f-g. E. hamigerum - f. lâmina foliar; g. porção apical do ramo com catafilos, estípula e botão floral. h-j. E. leal-costae - h. ramo com catafilos, estípula e lâmina foliar; i. ramo com detalhes dos catafilos; j. flor brevistila. k-1. E. martii-k. estípula; 1. drupa. m-o. E. mattos-silvae - m. ramo com catafilos, bractéolas espiraladas, botões florais e drupa; n. ramo; o. estípula.

Figure 3 -a-c. E. flaccidum - a. branch with cataphyll and stipules; b. long-styled flower; c. stipule. d-e. E. grandifolium - d. branch with cataphylls, stipule and leaf; e. cross section of drupe. f-g. E. hamigerum -f. leaf; g. detail of twig apex with cataphylls, stipule and flower bud. h-j. E. leal-costae - h. branch with cataphylls, stipule and leaf; i. branch, detail of cataphylls; j. short-styled flower. k-1. E. martiik. stipule; 1. drupe. m-o. E. mattos-silvae - m. branch with cataphylls, spirally bracteoles, flower buds and drupe; n. branch; o. stipule. 
a ovais, maiores que o tubo estaminal; pétalas de coloração creme ou esbranquiçadas, 4,5-3 × 2-2,3 $\mathrm{mm}$, elípticas; tubo estaminal ca. $2 \mathrm{~mm}$ compr., margem crenulada, ovário ca. $2 \mathrm{~mm}$ compr., oblongo. Flor brevistila: estames ca. $3 \mathrm{~mm}$ compr., estiletes ca. $1 \mathrm{~mm}$ compr., conatos $1 / 3$ a $1 / 2$ compr. Flor longistila: estames opositissépalos ca. 1,3 mm compr., alternissépalos ca. $2 \mathrm{~mm}$ compr.; estiletes ca. $3 \mathrm{~mm}$ compr., conatos $2 / 3$ compr. Drupa 10-16 $\times$ 4-6 mm, falcada, endocarpo 3-sulcado.

Erythroxylum grandifolium foi registrada apenas na região sul da Bahia (Loiola 2013) em floresta ombrófila montanas, submontanas e de terras baixas. Pertence a Erythroxylum sect. Megalophyllum O.E. Schulz e apresenta similaridade com E. splendidum (ver comentários nesta última). Indivíduos encontrados em altitudes acima de 700 metros apresentaram porte e lâminas foliares menores e podem ser confundidos com E. cuspidifolium, mas o ramo esbranquiçado, o pedicelo 2-3 mm compr., a drupa falcada com endocarpo 3-sulcado e os três lóculos desenvolvidos permitem sua distinção.

Material selecionado: BRASIL. BAHIA: Arataca $15^{\circ} 12^{\prime} 10^{\prime}$ 'S, 39²4'29”'W, 29.III.2008, fr., A.M. Amorim et al. 7216 (CEPEC). Camamu, 23.VII.1981, fr., A.M. de Carvalho \& J. Gatti 744 (CEPEC). Itacaré, 14²5' 5”S, 39॰35'5'W, 12.II.2011, fl. e fr., T. Araújo et al. 36 (CEPEC). Itambé, 24.IV.1972, fr., T.S. Santos 2268 (CEPEC). Santa Terezinha, 1251'35'S, 39²8'26”W, 28.III.2013, fl. e fr., T. Araújo \& M. Nogueira 179 (CEPEC, HUEFS, SPF). Una, 18.X.1983, fl., T.S. Santos 3909 (CEPEC).

\section{Erythroxylum hamigerum O.E. Schulz in} Engl., Pflanzenr. 4(134): 23. $1907 . \quad$ Fig. 3f-g

Arbusto ou árvore 3-15 m alt., ramo castanho; lenticelas pouco numerosas, distribuídas por todo o ramo. Catafilos do mesmo tamanho que as estípulas, numerosos, distribuídos por todo o ramo, congestos; Estípulas persistentes, 5-8 $\mathrm{mm}$ compr., triangulares, estriadas, margem fimbriada, ápice agudo, 3-setulado; pecíolo 4-5 mm compr. Lâmina foliar 8-14 × 3,5-6 cm, cartácea a coriácea, elíptica, raramente oblonga, face adaxial verde escura, brilhante, abaxial verde clara, opaca, base cuneada, margem plana, ápice agudo. Fascículo 1-3 flores, bractéolas 3, ca. $3 \mathrm{~mm}$ compr., estreitamente triangulares, não estriadas, margem fimbriada. Flor subséssil; cálice verde, lobos 6-7 × 2-2,8 mm, ovais, conspicuamente maiores que o tubo estaminal; pétalas de coloração creme ou esbranquiçadas, ca. $6 \times 3 \mathrm{~mm}$, oblongas; tubo estaminal 2,5-3 $\mathrm{mm}$ compr., margem crenulada, ovário ca. $2 \mathrm{~mm}$ compr., oblongo. Flor brevistila: estames 4,5-5 $\mathrm{mm}$ compr., estiletes ca. 2,5 mm compr., livres. Flor longistila: estames opositissépalos ca. $2 \mathrm{~mm}$ compr., alternissépalos ca. $4 \mathrm{~mm}$ compr; estiletes ca. $6 \mathrm{~mm}$ compr., livres. Drupa 10-15 × 4-6 mm, oval, endocarpo 6-sulcado.

Erythroxylum hamigerum apresenta distribuição restrita à Bahia (Loiola 2013) ocorrendo em floresta ombrófila montana, submontana e de terras baixas. Pertence a Erythroxylum sect. Macrocalyx O.E. Schulz e durante a análise das coleções notou-se um grande número de amostras de E. hamigerum determinadas E. macrocalyx Mart., porém E. hamigerum apresenta estípulas de 5-8 mm compr. com margem fimbriada e flores subsésseis, enquanto E. macrocalyx apresenta estípulas com ca. $2 \mathrm{~mm}$ compr. com margem inteira e flores pediceladas. Além disso, constatou-se a ocorrência de E. hamigerum apenas na Mata Atlântica e E. macrocalyx, na Bahia, ocorre exclusivamente em Cerrado e Caatinga.

Material selecionado: BRASIL. BAHIA: Arataca, 15'10'42'S, 39²0'9'W, 12.X.2008, fl., J.G. Jardim et al. 5407 (CEPEC). Ilhéus 9.I.1983, bot., A.M. de Carvalho et al. 1365 (CEPEC). Porto Seguro 16²8'57'S, 3907'11'W, IV.2013, est., T. Araújo \& M. Nogueira 206 (CEPEC). Santa Cruz Cabrália, 18.I.1984, est., F.S. Santos 150 (CEPEC). Una, $15^{\circ} 15^{\prime}$ 'S, $39^{\circ} 15^{\prime} \mathrm{W}$, s.d., fl., M. Sobral et al. 5803 (CEPEC).

12. Erythroxylum leal-costae Plowman Bot. Mus. Leafl. 29: 273. 1983.

Fig. $3 h-j$

Arbusto ou arvoreta 1,2-3 m alt., ramo espessado, compresso, castanho escuro ou enegrecido, transversalmente estriado, lenticelas pouco numerosas, distribuídas por todo o ramo. Catafilos do mesmo tamanho que as estípulas, numerosos, presentes nos ramos de crescimento curto, dísticos, congestos; Estípulas persistentes, 2-3,5 mm compr., largamente triangulares, estriadas, margem inteira, ápice agudo, 3-setulado, sétulas frequentemente com margem erosa; pecíolo 1,5-2,5 mm compr. Lâmina foliar 2-6 × 2-4,5 $\mathrm{cm}$, coriácea, oboval, elíptica ou largamente elíptica, face adaxial verde escura brilhante, abaxial verde clara, opaca, base cuneada ou arredondada, margem plana, ápice arredondado ou retuso. Fascículo 1-8 flores, bractéolas 3, ca. $1 \mathrm{~mm}$ compr., ovais a triangulares, não estriadas, margem inteira. Flor subséssil com pedicelo de 1-1,5 mm compr.; cálice verde, lobos 1-1,5 × 0,6-0,8 mm compr., triangulares, menores que o 
tubo estaminal; pétalas de coloração creme, 2-2,5 $\times 1,5-2 \mathrm{~mm}$, oblongas ou ovais; tubo estaminal 1,2-1,5 mm compr., margem denticulada, ovário ca. $1 \mathrm{~mm}$ compr., oblongo. Flor brevistila: estames ca. $2 \mathrm{~mm}$ compr., estiletes ca. $1 \mathrm{~mm}$ compr. livres Flor longistila: estames opositissépalos ca. $1 \mathrm{~mm}$ compr., alternissépalos ca. 1,5 mm compr; estiletes 1,7-2 mm compr. livres. Drupa 8-10 mm compr., oblonga, endocarpo 3-sulcado.

Erythroxylum leal-costae é restrito a Bahia (Loiola, 2013) e foi coletada em áreas de restinga e duna. Atualmente consta na lista de flora brasileira ameaçadas de extinção (Brasil 2008). Pertence a Erythroxylum sect. Rhabdophyllum e pode ser reconhecida por seus ramos espessados, compressos, castanhos escuros ou enegrecidos, transversalmente estriados, lâminas foliares coriáceas com ápice arredondado ou retuso, e lobos do cálice menores que o tubo estaminal.

Material selecionado: BRASIL. BAHIA: Mata de São João, 25.II.1986, est., G.C.P. Pinto \& H.P. Batista 12/86 (ALCB, CEPEC, HRB). Salvador, 23.III.1975, fl. e fr., A. Leal Costa (ALCB 05045).

13. Erythroxylum martii Peyr. in Mart., Eichler \& Urb., Fl. bras. 12(1): 160. $1878 . \quad$ Fig. 3f-1

Arbusto 1-3 m alt., ramo castanho escuro; lenticelas distribuídas por todo o ramo. Catafilos do mesmo tamanho que as estípulas, numerosos, esparsos; Estípulas persistentes, 8-20 mm compr., membranáceas, estreitamente triangulares, não estriadas, margem inteira, ápice agudo, 2-setulado; pecíolo 4-15 mm compr. Lâmina foliar 9-20 × 3-9 cm, membranácea, estreitamente elíptica a largamente elíptica, face adaxial verde escura, abaxial verde clara, opaca, base cuneada, margem plana, ápice acuminado, às vezes cuspidado. Fascículo 1-3 flores, bractéolas 2, ca. 1,5 mm compr., estreitamente triangulares, lisas, margem inteira. Flor com pedicelo de ca. $4 \mathrm{~mm}$ compr.; cálice verde, lobos ca. $2 \times 1,5 \mathrm{~mm}$, triangulares a ovais, pouco maiores que o tubo estaminal; pétalas amareladas, ca. $5 \times 2 \mathrm{~mm}$, oblongas; tubo estaminal ca. $1,5 \mathrm{~mm}$ compr., margem crenulada, ovário ca. $2 \mathrm{~mm}$ compr., oblongo. Flor brevistila: estames ca. $2 \mathrm{~mm}$ compr., estiletes ca. $1 \mathrm{~mm}$ compr., livres. Flor longistila: estames opositissépalos ca. $1 \mathrm{~mm}$ compr., alternissépalos ca. $2 \mathrm{~mm}$ compr.; estiletes ca. $3 \mathrm{~mm}$ compr., livres. Drupa $10-15 \times 3-5 \mathrm{~mm}$, oblonga, endocarpo 6-sulcado.

Erythroxylum martii possui distribuição restrita à Bahia (Loiola 2013; Plowman \& Hensold
2004), onde cresce no sub-bosque de floresta ombrófila de terras baixas, mas pode alcançar regiões submontanas e montanas. Pertence a Erythroxylum sect. Archerythroxylum e pode ser distinta das demais espécies pelas estípulas alongadas (8-20 mm compr.), membranáceas, não estriadas e com ápice 2-setulado, lâmina foliar relativamente grande $(9-20 \times 3-9 \mathrm{~cm})$, pétalas oblongas ca. $5 \mathrm{~mm}$ compr. e drupas com endocarpo 6-sulcado.

Material selecionado: BRASIL. BAHIA: Amargosa, $13^{\circ} 05^{\prime} 56^{\prime}$ 'S, 39 39'08'W, 29.I.2007, fl., D. Cardoso et al. 1703 (CEPEC, HUEFS). Ilhéus, $14^{\circ} 52^{\prime} \mathrm{S}, 39^{\circ} 04^{\prime} \mathrm{W}$, 18.III.1998, fl., S. Ginzbarg \& J.L. Hage 774 (CEPEC). Ituberá, $13^{\circ} 40^{\prime} \mathrm{S}, 39^{\circ} 07^{\prime} \mathrm{W}, 4 . \mathrm{II} .1983$, fr., T. Plowman \& A.M. de Carvaho 12805 (CEPEC, F). Santa Terezinha, 26.III.2013, fl., T. Araújo \& M. Nogueira 178 (CEPEC). Taperoá, 21.IX.1988, est., L.A. Mattos Silva et al. 2568 (CEPEC). Wenceslau Guimarães, 22.V.2005, fr., A.M. Amorim et al. 5110 (CEPEC).

14. Erythroxylum mattos-silvae Plowman, Fieldiana, Bot., 19: 12. $1987 . \quad$ Fig. 3m-o

Arbusto ou arvoreta 1-5 m alt., ramo castanho acinzentado a castanho escuro, frequentemente com fissuras transversais nas porções mais velhas; lenticelas numerosas, distribuídas por todo o ramo. Catafilos menores que as estípulas, numerosos, presentes em todo o ramo, esparsos; Estípulas persistentes, 2-3,5 $\mathrm{mm}$ compr., largamente triangulares, estriadas, margem inteira, ápice arredondado, 3-setulado; pecíolo 6-15 mm compr. Lâmina foliar 10-25 ×3,9-10 cm, coriácea, elíptica a largamente elíptica, oblonga, oboval, face adaxial verde escura, abaxial verde clara, opaca, base cuneada, margem plana, ápice agudo a acuminado, às vezes arredondado ou cuspidado. Fascículo 1-15 flores, bractéolas $6-9$, ca. 1,5 mm compr., espiraladas, imbricadas, ovais, estriadas, margem inteira. Flor com pedicelo de $1-1,5 \mathrm{~mm}$ compr.; cálice verde a ocre, lobos $0,5-1 \mathrm{~mm}$ compr., triangulares a estreitamente triangulares, pouco menores que o tubo estaminal; pétalas de coloração creme, 2,2-3,5 $\times 0,8-1,2 \mathrm{~mm}$, oblongas; tubo estaminal ca. 1,7 mm compr., margem crenulada, ovário ca. 1,2 mm compr., oblongo. Flor brevistila: estames $0,7-1,3 \mathrm{~mm}$ compr., estiletes $0,9-1,2$ $\mathrm{mm}$ compr., livre, às vezes conatos na base. Flor longistila: estames opositissépalos ca. $0,7 \mathrm{~mm}$ compr., alternissépalos ca. 1,1 mm compr; estiletes ca. $1,5 \mathrm{~mm}$ compr. conatos $2 / 3$ compr. Drupa $12-16$ $\mathrm{mm}$ compr., oblonga, endocarpo liso. 
Os registros de ocorrência de Erythroxylum mattos-silvae limitam-se à Bahia (Loiola 2013), principalmente em floresta ombrófila de terras baixas e restinga arbórea. Atualmente a espécie encontra-se na lista de flora brasileira ameaçadas de extinção (Brasil 2008). Pertence a Erythroxylum sect. Rhabdophyllum e apresenta similaridade com E. nobile, principalmente no aspecto geral dos ramos e folhas. Contudo em E. mattos-silvae as estípulas são menores (2-3,5 mm compr. vs. 6-11 $\mathrm{mm}$ compr. em $E$. nobile) e largamente triangulares (vs. triangulares em $E$. nobile). Quando fértil, a espécie pode ser reconhecida pelos pedicelos florais curtos (1-1,5 mm compr.) com 6-9 bractéolas espiraladas na base e estiletes conatos em $2 / 3$ compr. nas flores longistilas.

Material selecionado: BRASIL. BAHIA: Gandu, 29.III.2013, fr., T. Araújo \& M. Nogueira 182 (CEPEC, HUEFS). Ilhéus, 26.II.1985, est., T. Plowman et al. 13958 (CEPEC, F). Una, 22.IX.1992. fl., A.M. Amorim et al. 755 (ALCB).

\section{Erythroxylum membranaceum Plowman,} Fieldiana, Bot., 19: 17. 1987.

Fig. $4 \mathrm{a}-\mathrm{b}$

Arbusto 1,5-3 m alt., ramo castanho escuro, lenticelas pouco numerosas, distribuídas por todo o ramo. Catafilos do mesmo tamanho que as estípulas, pouco numerosos, presentes em todo o ramo, esparsos; Estípulas persistentes, 2-3 mm compr., triangulares, estriadas, margem inteira, ápice agudo, 3-setulado; pecíolo 5-8 mm compr. Lâmina foliar 5-14 × 3-7,5 cm, membranácea, elíptica, oval, face adaxial verde escura brilhante, abaxial verde clara, opaca, base cuneada ou arredondada, margem plana ou levemente ondulada, ápice agudo a obtuso. Fascículo 1-4 flores, bractéolas 3, ca. 1 $\mathrm{mm}$ compr., triangulares, estriadas, margem inteira. Flor com pedicelo de 3-4 mm compr.; cálice verde, lobos ca. 1,5 $\times 1 \mathrm{~mm}$ compr., triangulares, do mesmo tamanho ou pouco maiores que o tubo estaminal; pétalas esbranquiçadas ou de coloração creme, ca. $2 \times 1 \mathrm{~mm}$, oblongas; tubo estaminal 1-1,5 mm compr., margem denticulada, ovário ca. $1 \mathrm{~mm}$ compr., oblongo. Flor brevistila: estames ca. $2 \mathrm{~mm}$ compr., estiletes ca. $1 \mathrm{~mm}$ compr., livres. Flor longistila: estames opositissépalos ca. $1 \mathrm{~mm}$ compr., alternissépalos ca. 1,5 mm compr.; estiletes 2-2,3 mm compr., livres. Drupa 8-12 mm compr., oval, endocarpo liso.

Erythroxylum membranaceum possui distribuição restrita à Bahia (Loiola 2013) com registro apenas para Aurelino Leal (Plowman
1984) e Itapebi (Loiola 2001), atualmente consta na lista de flora brasileira ameaçadas de extinção (Brasil 2008). Pertence a Erythroxylum sect. Rhabdophyllum e assemelha-se a E. compressum, $E$. distortum e E. tenue pelo hábito arbustivo até $3 \mathrm{~m}$ alt. e pelas estípulas estriadas $2-3 \mathrm{~mm}$ compr., mas pode ser diferenciada destas pelo pecíolo maior, 5-8 $\mathrm{mm}$ compr., (vs. ca. 1,5 $\mathrm{mm}$ compr. em E. compressum, 2-3 mm compr. em $E$. distortum e 3-5 mm em E. tenue). Além disso, distingue-se de $E$. distortum pelos lobos do mesmo tamanho ou maiores que o tubo estaminal vs. lobos conspicuamente menores que o tubo estaminal em $E$. distortum, e de $E$. tenue pelo número de bractéolas ( 3 em E. membranaceum vs. 6 ou mais em E. tenue). Pela primeira vez as pétalas e flores longistilas de E. membranaceum são descritas.

Material selecionado: BRASIL. BAHIA: Aurelino leal, $14^{\circ} 20^{\prime} 72^{\prime \prime}$ 'S, 39²2'91"W, 30.X.2001, fl. e fr., W. Thomas et al. 12689 (CEPEC).

16. Erythroxylum mikanii Peyr. in Mart., Eichler \& Urb., Fl. bras. 12(1): 138. $1878 . \quad$ Fig.4 c-d Arbusto 1-4 m alt., densamente ramificado, ramo castanho-claro, às vezes acinzentado; lenticelas numerosas, distribuídas por grandes porções do ramo. Catafilos do mesmo tamanho que as estípulas, numerosos, dísticos, ocasionalmente com margem fimbriada, congestos nos ramos floríferos e/ou nos ramos de crescimento curto; Estípulas persistentes, 2-4 mm compr., triangulares, estriadas, margem fimbriada (quando jovens), ápice agudo, curtamente 3-setulado; pecíolo 1-3 mm compr. Lâmina foliar $3-5,5 \times 1,8-2,5 \mathrm{~cm}$, cartácea, elíptica a oboval, face adaxial verde escura, face abaxial verde, às vezes acinzentada, opaca, base cuneada, margem plana, ápice agudo a arredondado. Fascículo reduzido a uma flor, bractéolas 3, ca. 1,5 $\mathrm{mm}$ compr., lanceoladas, estriadas, margem erosa-fimbriada. Flor com pedicelo de 2-3 mm compr., cálice verde, lobos ca. $2 \times 1 \mathrm{~mm}$, estreitamente triangulares, maiores que o tubo estaminal; pétalas esbranquiçadas, 2,5-3 × 1-1,5 mm, elípticas; tubo estaminal 1-1,3 mm compr., margem crenulada; ovário ca. $1 \mathrm{~mm}$ compr., oblongo. Flor brevistila: estames 2,7-3 $\mathrm{mm}$ compr., estiletes ca. $1 \mathrm{~mm}$ compr., livres. Flor longistila: estames opositissépalos ca. $0,8 \mathrm{~mm}$ compr., alternissépalos ca. 1,3 mm compr.; estiletes ca. $3 \mathrm{~mm}$ compr., livres. Drupa 6-10 × 4-5 mm, oblonga a oval, endocarpo liso. 

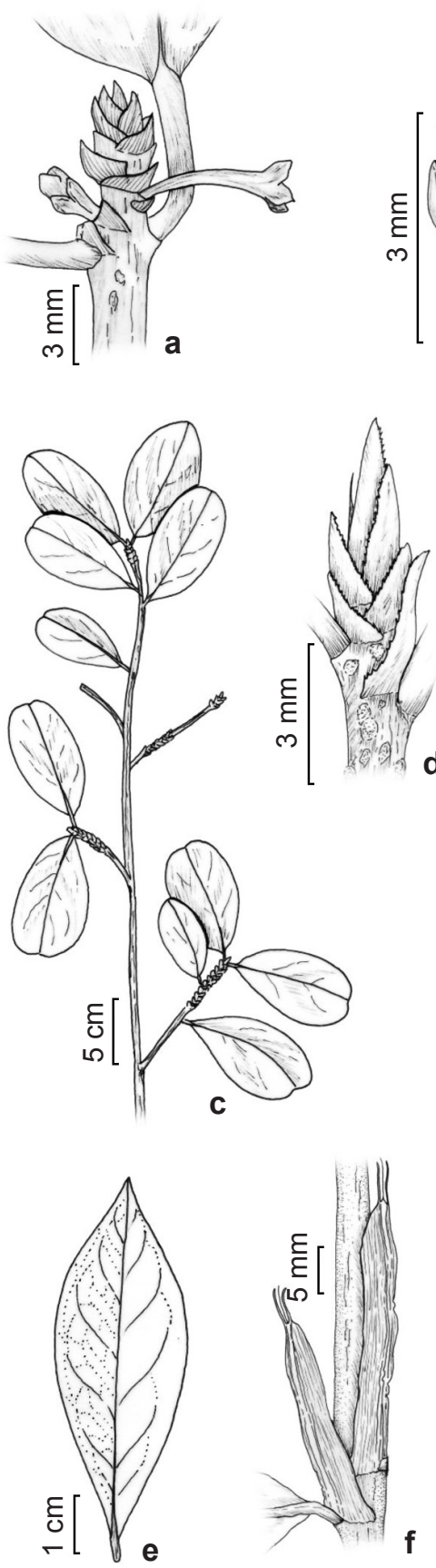
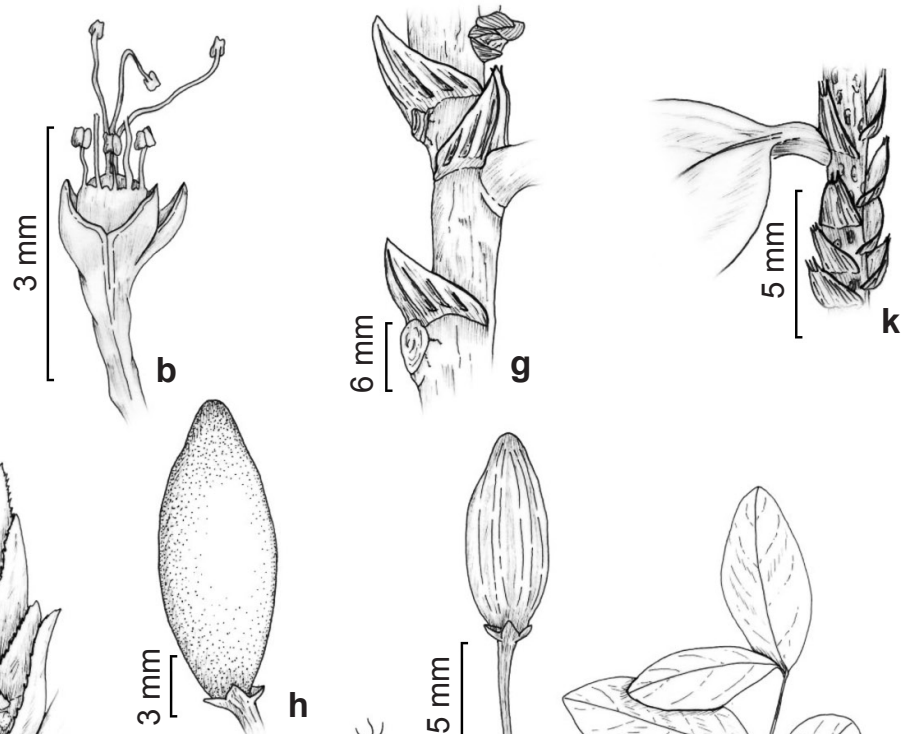

h
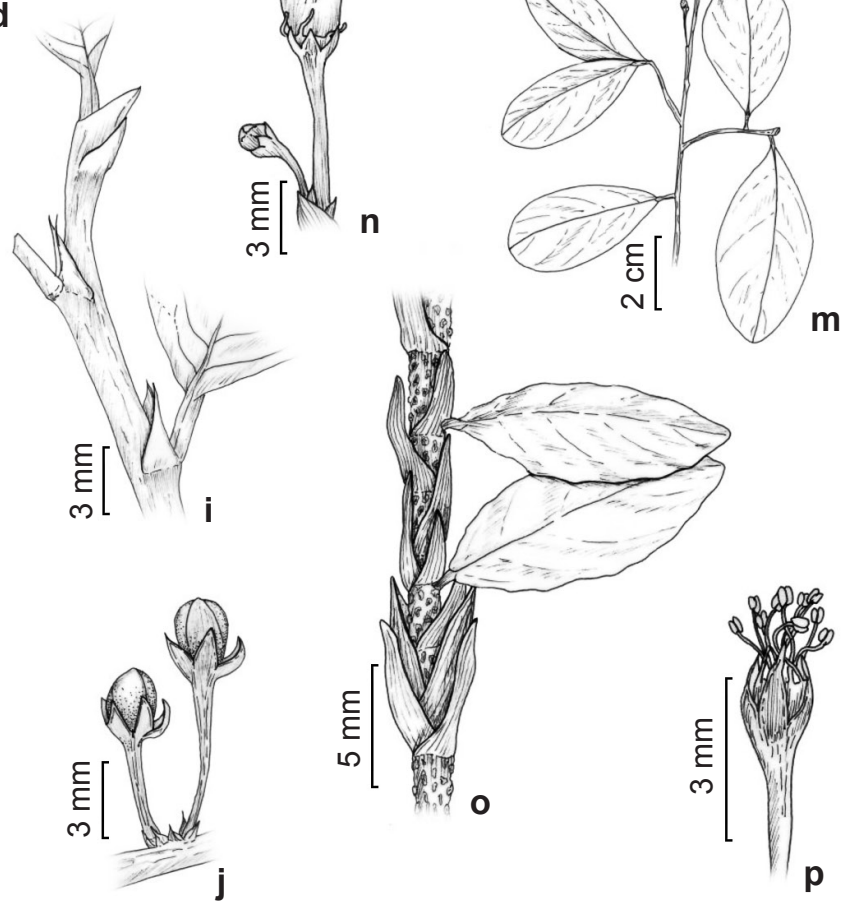

Figura 4 - a-b. E. membranaceum - a. ápice do ramo com catafilos, estípulas e pedicelo; b. flor longistila. c-d. E. mikanii - c. ramo; d. ápice do ramo com estípulas e catafilos com margem fimbriada. e-f. E. mucronatum - e. lâmina foliar; f. ramo com catafilo estípula. g-h. E. nobile - g. ramo com catafilos e estípulas; h. drupa. i-j. E. ochranthum - i. ramo com estípulas e pecíolo; j. botões florais. k-1. E. passerinum - k. ramo com catafilos e estípula; 1. drupa. m-n. E. petrae-caballi - m. hábito; n. catafilo, botão floral e drupa. o-p. E. polygonoides - o. ramo com catafilos, estípulas e lâmina foliar; p. flor brevistila.

Figure 4-a-b. E. membranaceum - a. twig apex with cataphylls, stipules and pedicel; b. long-styled flower. c-d. E. mikanii-c. branch; d. twig apex with fimbriate stipules and cataphylls. e-f. E. mucronatum - e. leaf; f. branch with stipule. g-h. E. nobile - g. branch with cataphylls and stipules; h. drupe. i-j. E. ochranthum - i. branch with stipule and petiole; j. flower buds. k-1. E. passerinum - k. branch with cataphylls and stipule; 1 . drupe. m-n. E. petrae-caballi-m. habit; n. cataphyll, flower bud and drupe. o-p. E. polygonoides - o. branch with cataphylls, stipule and leaf; p. short-styled flower. 
Existem registros de Erythroxylum mikanii na Bahia, Rio de Janeiro e Sergipe (Loiola 2013). $\mathrm{Na}$ Bahia, a espécie desenvolve-se em restinga arbustiva e/ou arbórea ou floresta ombrófila densa de terras baixas. Pertence a Erythroxylum sect. Rhabdophyllum e pode ser confundida com $E$. passerinum devido ao porte arbustivo com ramos densamente lenticelados, e com E. distortum pelas lâminas foliares geralmente obovais, mas não raro elípticas ou ovais e fascículos reduzidos a uma única flor. Quando jovens, as estípulas de E. mikanii apresentam a margem fimbriada, o que permite sua distinção em relação às espécies anteriormente mencionadas, cujas estípulas possuem a margem inteira.

Material selecionado: BRASIL. BAHIA: Cairu, 20.XI.1985, fl., L.A. Mattos Silva \& T.S. Santos 1912

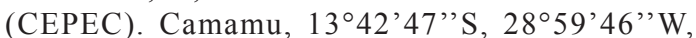
16XI.2002, fl., P. Fiaschi et al. 1164 (CEPEC, SPF). Ilhéus, 27.II.1985, fl., T. Plowman et al. 13969 (CEPEC). Itacaré, $14^{\circ} 25^{\prime} 05^{\prime \prime} \mathrm{S}, 39^{\circ} 33^{\prime} 05^{\prime} \mathrm{W}, 12 . \mathrm{II} .2011$, est., T. Araújo et al. 41 (CEPEC). Santo Antônio de Jesus, 30.I.1993, fl. e fr., J.R. Pirani \& J.A. Kallunki 2734 (CEPEC, SPF). Valença, 6.II.1983, fl., T. Plowman \& A.M. de Carvalho 12817 (CEPEC).

17. Erythroxylum mucronatum Benth., London J. Bot. 2: 372.1843.

Fig. $4 \mathrm{e}-\mathrm{f}$

Arbusto ou arvoreta 3-6 m alt., ramo castanho acinzentado a castanho escuro, lenticelas pouco numerosas, distribuídas por todo o ramo. Catafilos maiores que as estípulas, numerosos, adensados nas porções jovens do ramo; Estípulas persistentes, 10-25 mm compr., estreitamente triangulares, estriadas, margem inteira, ápice agudo, longamente 3-setulado; pecíolo $2-3 \mathrm{~mm}$ compr. Lâmina foliar 5-14 × 3-6 cm, cartácea, elíptica, face adaxial verde escura, abaxial verde clara, opaca, base cuneada, margem plana, ápice atenuado, mucronado. Fascículo 1-15 flores, bractéolas 2, 0,8-1,2 mm compr., cimbiformes, lisas ou inconspicuamente estriadas, margem inteira ou fimbriadas. Flor com pedicelo de $3-5$ mm compr.; cálice verde, lobos 1-1,5 × 0,5-1 mm, triangulares, maiores que o tubo estaminal; pétalas esbranquiçadas, 3,5-4 × 1-1,6 mm, oblongas; tubo estaminal ca. 1,5 $\mathrm{mm}$ compr., margem crenulada, ovário 1,5-2 mm compr., oblongo. Flor brevistila: estames $2-2,5 \mathrm{~mm}$ compr., estiletes 1-1,5 mm compr., livres. Flor longistila: estames opositissépalos ca. $1 \mathrm{~mm}$ compr., alternissépalos ca. $1,5 \mathrm{~mm}$ compr., estiletes $2-2,5 \mathrm{~mm}$ compr. livres. Drupa 8-11 mm compr., oblonga, endocarpo liso.
Erythroxylum mucronatum distribui-se por toda América do Sul, e no Brasil ocorre nas Regiões Centro-Oeste, Nordeste e Norte (Plowman \& Hensold 2004). Foi encontrada na Bahia em floresta ombrófila e floresta estacional semidecidual. Pertence a Erythroxylum sect. Rhabdophyllum e compartilha semelhanças morfológicas e de distribuição geográfica com E. citrifolium. Ver diferenças entre estas nos comentários de $E$. citrifolium.

Material selecionado: BRASIL. BAHIA: Camaçari, 7.II.1995, fr., M.L. Guedes \& E.M. Silva 6735 (ALCB, CEPEC). Camamu, 14'01'28'S, 39॰09'06”'W, 25.VII.2001, fr., L.A. Mattos Silva et al. 4382 (CEPEC, HUESC). Ituberá, $13^{\circ} 47^{\prime} 0^{\prime}$ S, 39 $9^{\circ} 10^{\prime} 21^{\prime \prime} \mathrm{W}, 31 . \mathrm{III} .2013$, fl. e fr., T. Araújo \& M. Nogueira 189 (CEPEC, HUFS). Nilo Peçanha, 19.II.1975, fl. e fr., T.S. Santos 2860 (CEPEC). Taperoá, 21.IX.1988, fr., L.A. Mattos Silva et al. 2563 (CEPEC, MBM). Valença, 10.I.1992, A.M. de Carvalho 1138 (RB).

18. Erythroxylum nobile O.E. Schulz in Engl., Pflanzenr. (4)134: 37. $1907 . \quad$ Fig. 4g-h

Arbusto ou árvore 1-8 m alt., ramo castanhoacinzentado; lenticelas numerosas, distribuídas por todo o ramo, exceto nas porções jovens. Catafilos do mesmo tamanho que as estípulas, numerosos, presentes em todo o ramo, esparsos; Estípulas persistentes, 6-11 mm compr., membranáceas, triangulares, estriadas, margem inteira, ápice agudo, 3-setulado; pecíolo 6-20 $\mathrm{mm}$ compr. Lâmina foliar 7-26 × 3-15 cm, membranácea, elíptica, às vezes oval, face adaxial verde escura e brilhante, abaxial verde clara, opaca, base cuneada a arredondada, margem plana, ápice agudo. Fascículo 1-4 flores, bractéolas 3, 2-3 mm compr., triangulares, estriadas, margem inteira. Flor com pedicelo de 1-3 mm compr.; cálice verde, lobos ca. $1,5 \times 1 \mathrm{~mm}$, triangulares, pouco maiores que o tubo estaminal; pétalas de coloração creme, ca. $2 \times 1 \mathrm{~mm}$, oblongas; tubo estaminal ca. $1 \mathrm{~mm}$ compr., margem crenulada, ovário 1-1,5 $\mathrm{mm}$ compr., oblongo. Flor brevistila: estames ca. $3 \mathrm{~mm}$ compr., estiletes ca. $1 \mathrm{~mm}$ compr., livres. Flor longistila: estames opositissépalos ca. $1 \mathrm{~mm}$ compr., alternissépalos ca. 1,5 mm compr.; estiletes 2,5-3 mm compr. livres. Drupa 8-10 mm compr., oblonga, endocarpo liso.

Erythroxylum nobile foi registrada até o momento nos estados de Alagoas, Bahia e Sergipe (Loiola 2001, 2004). Na Bahia a espécie ocorre em floresta ombrófila de terras baixas, floresta estacional submontana, restinga arbórea e mussununga. Pertence a Erythroxylum sect. 
Rhabdophyllum e está entre as espécies que apresentam estípulas estriadas e relativamente grandes (p. ex. E. bradeanum, E. citrifolium, E. columbinum, E. hamigerum, E. mucronatum e E. polygonoides), mas pode ser diferenciada das demais pelos pecíolos alongados (6-20 mm compr.) e pedicelos curtos ( ca. $3 \mathrm{~mm}$ compr.).

Material selecionado: BRASIL. BAHIA: Almadina,

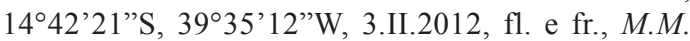
Coelho 626 (CEPEC). Ilhéus, $14^{\circ} 46^{\prime} 55^{\prime}$ 'S, 39 $09^{\circ} 04^{\prime} 09^{\prime \prime} \mathrm{W}$, 17.IX.1994, fl., W. Thomas et al. 10509 (CEPEC). Itapebi, 10.XI.1967, fl., R.S. Pinheiro et al. 418 (CEPEC). Itiruçu, 29.II.1988, fl., L.A. Mattos Silva et al. 2231 (CEPEC). Prado, $17^{\circ} 05^{\prime} 09^{\prime \prime} \mathrm{S}, 39^{\circ} 19^{\prime} 19^{\prime \prime} \mathrm{W}$, IV.2013, est., T. Araújo \& M. Nogueira 203 (CEPEC). Una, 18.X.1983, fl., T.S. Santos 3886 (CEPEC). Valença, 25.II.2986, fr., J.L. Hage et al. 1956 (CEPEC).

19. Erythroxylum ochranthum Mart., Abh. Math.Phys. Cl. Königl. Bayer. Akad. Wiss. 3(2): 371. 1843.

Fig. 4i-j

Arbusto ou arvoreta de 1-8 m alt., ramo castanho acinzentado a castanho escuro, lenticelas numerosas, distribuídas por todo o ramo. Catafilos do mesmo tamanho que as estípulas, pouco numerosos, presentes por todo ramo, esparsos; Estípulas persistentes, 3-6 mm compr., triangulares, não estriadas, margem inteira, ápice arredondado, 3-setulado; pecíolo 2-4 mm compr. Lâmina foliar 5-11 × 2,5-4,5 cm, cartácea, elíptica a oboval, face adaxial verde escura brilhante, abaxial verde clara, opaca, base cuneada, margem plana, ápice agudo ou arredondado. Fascículo 1-9 flores, bractéolas 2, 1,8-2,2 mm compr., oblongas, lisas, margem inteira. Flor com pedicelo de 4-10 mm compr.; cálice verde, lobos $2-2,5 \times 0,7-1,1$ $\mathrm{mm}$, triangulares, maiores que o tubo estaminal; pétalas esbranquiçadas, $3-3,5 \times 1-1,4 \mathrm{~mm}$, oblongas; tubo estaminal ca. $1 \mathrm{~mm}$ compr., margem crenulada, ovário 1,5-2 mm compr., oblongo. Flor brevistila: estames ca. $3 \mathrm{~mm}$ compr., estiletes 1,5-2 mm compr., livres Flor longistila: estames opositissépalos ca. $1 \mathrm{~mm}$ compr., alternissépalos ca. $2 \mathrm{~mm}$ compr; estiletes $4-5 \mathrm{~mm}$ compr. livres. Drupa 10-16 mm compr., oblonga, endocarpo 6-sulcado.

Esta espécie possui registros na Bahia e Paraíba (Loiola 2013) e desenvolve-se tanto em Mata Atlântica quanto Caatinga. Na Bahia, além da Caatinga (Loiola 2013) é encontrada em floresta estacional semidecidual e floresta ombrófila de terras baixas. Pertence a Erythroxylum sect. Archerythroxylum e pode ser reconhecida pelas estípulas não estriadas com ápice arredondado, pedicelo 4-10 mm compr. com duas bractéolas oblongas não estriadas, lobos do cálice maiores que o tubo estaminal e estiletes das flores longistilas podendo atingir até ca. $5 \mathrm{~mm}$ compr.

Material selecionado: BRASIL. BAHIA: Conceição de Feira, 18.II.1981, fl., A.M. Carvalho et al. 567 (CEPEC). Ilhéus, 27.II.1985, est., T. Plowman et al. 13968 (CEPEC). Itabuna, 23.IX.1965, R.P. Belém 1801 (CEPEC). Itiruçu, 29.II.1988, fr., L.M. Mattos Silva et al. 2213 (CEPEC). Maracás, IV.1988, fl. e fr., L.A. Mattos Silva et al. 2269 (CEPEC).

20. Erythroxylum passerinum Mart., Abh. Math.Phys. Cl. Königl. Bayer. Akad. Wiss. 3(2): 386. 1843.

Fig. 4k-1

Arbusto ou árvore 1-9 m alt., ramo castanho; lenticelas numerosas, cobrindo todo o ramo e/ou concentradas nas porções jovens do ramo. Catafilos do mesmo tamanho que as estípulas, numerosos, congestos na base ou na porção jovem dos ramos, enegrecidos quando herborizados; Estípulas persistentes, 3-4,5 $\mathrm{mm}$ compr., enegrecidas quando herborizadas, triangulares, estriadas, margem inteira, ápice agudo, curtamente 3-setulado; pecíolo 1-3 mm compr. Lâmina foliar 4-11 $\times$ 2-5 cm, cartácea a coriácea, elíptica a largamente elíptica, face adaxial verde escura, frequentemente com máculas irregulares mais claras quando herborizada, face abaxial verde clara, opaca, base cuneada, margem plana, ápice agudo a arredondado. Fascículo 3-7 flores, bractéolas 2, ca. $1 \mathrm{~mm}$ compr., triangulares, estriadas, às vezes com margem fimbriada. Flor com pedicelo de 3-7 mm compr., delgado; cálice verde, lobos ca. 1,5 $\times 1 \mathrm{~mm}$, frequentemente com papilas conspícuas na face abaxial, triangulares, maiores que o tubo estaminal; pétalas esbranquiçadas ou amareladas, 2,5-3 $\times 1-1,5 \mathrm{~mm}$, oblongas; tubo estaminal 1-1,5 mm compr., margem crenulada, ovário ca. 1,5 $\mathrm{mm}$ compr., oblongo. Flor brevistila: estames ca. $3 \mathrm{~mm}$ compr., estiletes ca. 1,5 mm compr., livres. Flor longistila: estames opositissépalos ca. 1,5 mm compr., alternissépalos ca. $2 \mathrm{~mm}$ compr.; estiletes 3-4 mm compr., livres. Drupa 8-10 × 4-6 mm, oblonga a oval, endocarpo 6-sulcado.

Possui registros em Alagoas, Bahia, Maranhão, Paraíba, Pernambuco, Espírito Santo e Rio de Janeiro (Loiola 2013). Na Bahia ocorre principalmente em restinga ou floresta ombrófila densa de terras baixas. Pertence a Erythroxylum sect. Rhabdophyllum e assemelha-se morfologicamente a $E$. andrei e $E$.mikanii pelas estípulas estriadas e triangulares e pelo tamanho, formato e textura 
da lâmina foliar (ver comentários nestes táxons). Notou-se ainda que após a herborização, a face adaxial das folhas frequentemente apresenta máculas irregulares de coloração clara, que podem auxiliar seu reconhecimento em coleções de herbários.

Material selecionado: BRASIL. BAHIA: Belmonte, 7.I.1981, fr., A.M. de Carvalho \& J. Gatti 454 (CEPEC). Boa Nova, 14²4'14"S, 4009'16"W, 7.III.2003, fl., S.C. de Sant'Ana et al. 1085 (CEPEC). Ilhéus, 15.I.1990, fr., A.M. de Carvalho 2722 (CEPEC). Itabuna, $14^{\circ} 01^{\prime}$ 'S, 3901'W, 1.IV.1974, fr., R.M. Harley 17632 (CEPEC). Porto Seguro, $16^{\circ} 27^{\prime}$ S, 3904'W, 4.IV.1980, fr., R.M. Harley 21082 (CEPEC, K). Una, 29.X.1971, fl., R.S. Pinheiro 1668 (CEPEC).

\section{Erythroxylum petrae-caballi Plowman,} Fieldiana, Bot. 19: 20. $1987 . \quad$ Fig. 4m-n

Arbusto ou árvore 1-9 m alt., densamente ramificado, ramo castanho-claro ou castanho acinzentado; lenticelas pouco numerosas, distribuídas por todo o ramo. Catafilos do mesmo tamanho que as estípulas, dísticos, pouco numerosos, esparsos, às vezes condensados na base dos ramos jovens; Estípulas persistentes, 2-3 $\mathrm{mm}$ compr., triangulares, estriadas, margem erosa ou levemente fimbriada, ápice agudo, curtamente 3-setulado; pecíolo 1,5-3 mm compr. Lâmina foliar 3-6 × 1,8-2,5 cm, cartácea ou membranácea, elíptica a oval, face adaxial verde escura, opaca, face abaxial verde clara, opaca, base cuneada, margem plana, ápice agudo a arredondado. Fascículo 1-3 flores, bractéolas 2, ca. 1 mm compr., triangulares, não estriadas ou insconspicuamente estriadas, margem erosa ou fimbriada. Flor com pedicelo 7-11 mm compr., cálice verde, lobos ca. 2 $\times 1 \mathrm{~mm}$, triangulares, maiores que o tubo estaminal; pétalas amareladas, 1-1,5 × 1-1,2 mm, oblongas; tubo estaminal ca. $0,8 \mathrm{~mm}$ compr., margem inteira; ovário ca. 1-1,8 mm compr., oval ou elíptico. Flor brevistila: estames ca. 1,5 mm compr., estiletes ca. 0,7 mm compr., livres. Flor longistila: estames opositissépalos ca. $1 \mathrm{~mm}$ compr., alternissépalos ca. 1,5-1,7 mm compr.; estiletes 2-2,5 mm compr., livres. Drupa 8-10 × 4-5 mm, ampulácea ou oval, endocarpo liso.

Erythroxylum petrae-caballi possui distribuição restrita à Bahia (Loiola, 2013) e desenvolve-se principalmente em áreas de transição entre a Caatinga e a Mata Atlântica. Nesta última, ocorre mais frequentemente em floresta estacional decidual ou em floresta estacional semidecidual, sendo geralmente coletada às margens de córregos intermitentes. Atualmente consta na lista de flora brasileira ameaçadas de extinção (Brasil 2008). Pertence a Erythroxylum sect. Rhabdophyllum e apresenta semelhanças morfológicas com E. mikanii e E. distortum nas estípulas 2-3 mm compr., estriadas e triangulares. Pode ser diferenciada dessas duas espécies pela presença de 2 (vs. 3) bractéolas na base do pedicelo, pelos ramos com lenticelas pouco numerosas (vs. numerosas em E. mikanii) e flores com lobos do cálice maiores que o tubo estaminal (vs. menores que o tubo estaminal em E. distortum). Pela primeira vez as flores longistilas de E. petrae-caballi são descritas. Material selecionado: BRASIL. BAHIA: Cachoeira, XII.1980, fl. e fr., Grupo Pedra do Cavalo 967 (CEPEC). Feira de Santana, 28.I.1993, fl. e fr., L.P. de Queiroz et al. 3047 (HUEFS). Jussari, 4.I.2000, fl., F.S. Junchum et al. 03 (CEPEC).

22. Erythroxylum polygonoides Mart. Abh. Math.Phys. Cl. Königl. Bayer. Akad. Wiss. 3(2): 360. 1843.

Fig. 4o-p

Arbusto 1-4 m alt., ramo castanho acinzentado, lenticelas muito numerosas, frequentemente fundindo-se umas às outras, distribuídas por todo o ramo. Catafilos maiores que as estípulas, numerosos, presentes por todo o ramo, mas concentrados na porção apical dos mesmos, congestos; estípulas persistentes, 5-15 mm compr., triangulares, estriadas, margem inteira, ápice agudo, 2-setulado; pecíolo 2-3 mm compr. Lâmina foliar 3,5-9,5 × 2-5 cm, membranácea, elíptica, face adaxial verde escura brilhante, abaxial verde clara, opaca, base cuneada, margem ondulada, ápice agudo, frequentemente mucronado. Fascículo 3-8 flores, bractéolas 2, 2-3 mm compr., triangulares, estriadas, margem inteira. Flor com pedicelo de 3-5 mm compr.; cálice verde, lobos $1-1,3 \times 0,5-0,9 \mathrm{~mm}$ compr., triangulares ou estreitamente triangulares, maiores que o tubo estaminal; pétalas de coloração creme, amareladas ou esbranquiçadas, 3-3,5 $\times$ 1-1,5 mm, oblongas; tubo estaminal 1-1,5 mm compr., margem denticulada, ovário 1-1,5 mm compr., oblongo. Flor brevistila: estames 2-2,5 mm compr., estiletes ca. $1 \mathrm{~mm}$ compr., livres. Flor longistila: estames opositissépalos 0,5-1 mm compr., alternissépalos ca. 1,3-1,5 mm compr.; estiletes ca. $3 \mathrm{~mm}$ compr., livres. Drupa 8-12 mm compr., oblonga ou elíptica, endocarpo liso.

Erythroxylum polygonoides possui distribuição restrita ao Nordeste do Brasil, nos estados da Bahia, Pernambuco e Piauí 
(Loiola 2013). Na Bahia é mais abundante nos domínios da Caatinga e do Cerrado, mas é também encontrada em áreas de transição com a Mata Atlântica, principalmente em floresta estacional semidecidual e decidual. Pertence a Erythroxylum sect. Rhabdophyllum e, devido a suas estípulas alongadas $(5-15 \mathrm{~mm}$ compr.), pode ser confundida com E. citrifolium e E. mucronatum. Porém E. polygonoides possui ramos com lenticelas muito numerosas, frequentemente fundindo-se umas às outras, lâminas foliares membranáceas com margem ondulada e estípulas 2-setuladas, o que permite sua distinção das espécies anteriormente citadas. Material selecionado: BRASIL. BAHIA: Boa Nova, $14^{\circ} 22^{\prime} 25^{\prime}$ 'S, $40^{\circ} 11^{\prime} 15^{\prime}$ 'W, 8.III.2003, fr., P. Fiaschi et al. 1407 (CEPEC, HUEFS). Itiruçu, I.1988, fr., $M$. Sobral \& L.A. Mattos Silva 5829 (CEPEC). Poções, 14³6'40'S, 40²0'13"W, 7.II.2004, fl., W. Thomas et al. 13955 (CEPEC).

23. Erythroxylum pulchrum A. St-Hil., Fl. bras. merid. 2: 94. 1829.

Fig. 5a-c

Árvore 8-20 m alt., ramo castanho escuro, frequentemente tornando-se enegrecido após herborização, lenticelas pouco numerosas, distribuídas por todo o ramo. Catafilos do mesmo tamanho que as estípulas, pouco numerosos, presentes por todo o ramo, esparsos ou adensados na base dos ramos novos; Estípulas persistentes, 3-7,5 mm compr., triangulares ou largamente triangulares, lisas, margem inteira, ápice arredondado, 3-setulado; pecíolo 6-15 mm compr. Lâmina foliar 5-12(-24) × 2,5-7(-9) cm, coriácea, elíptica, largamente elíptica, oval, face adaxial verde escura conspicuamente brilhante, abaxial verde clara, opaca, base cuneada ou arredondada, margem plana ou levemente revoluta, ápice agudo ou arredondado. Fascículo 1-12(-29) flores, bractéolas 3, 1-1,5 $\mathrm{mm}$ compr., triangulares a largamente triangulares, lisas, margem inteira. Flor com pedicelo de 5-8 $\mathrm{mm}$ compr.; cálice verde, lobos 1-1,5 mm compr., triangulares, menores que o tubo estaminal; pétalas esbranquiçadas, $3-4,5 \times$ 1,5-2 mm, oblongas; tubo estaminal 1,5-2 mm compr., margem denticulada, ovário 1,5-2 $\mathrm{mm}$ compr., oblongo. Flor brevistila: estames 3-4 $\mathrm{mm}$ compr., estiletes $1,3-2 \mathrm{~mm}$ compr., livres Flor longistila: estames opositissépalos ca. $1 \mathrm{~mm}$ compr., alternissépalos ca. 1,5 mm compr; estiletes 3-4 mm compr., livres. Drupa 8-16 mm compr., oblonga ou elíptica, endocarpo 6-sulcado.
A espécie se distribui pelas Regiões Nordeste e Sudeste do país (Loiola 2013). Na Bahia ocorre principalmente na Mata Atlântica, em floresta ombrófila densa de terras baixas ou submontanas. Pertence a Erythroxylum sect. Leptogramme O.E. Schulz e dentre as espécies levantadas neste estudo é a que pode atingir maior porte (ca. 20 $\mathrm{m}$ alt.). Pode ser reconhecida pelas estípulas não estriadas, ápice arredondado, lâminas foliares com a face adaxial conspicuamente brilhante, lobos do cálice menores que o tubo estaminal e drupas com endocarpo 6-sulcado.

Material selecionado: BRASIL. BAHIA: Almadina, 14² $42^{\prime} 09^{\prime}$ 'S, 39²6'14"W, 7.VI.2012, fr., M.M. Coelho 735 (CEPEC). Camacã, 15²3'30”S, 39³3'55'W, 17.VII.2009, est., A.M. Amorim et al. 7878 (CEPEC). Ilhéus, $14^{\circ} 46^{\prime} 55^{\prime \prime} \mathrm{S} 30^{\circ} 04^{\prime} 09^{\prime \prime} \mathrm{W}, 23 . \mathrm{IX} .1994$, est., A.M. Carvalho et al. 5075 (CEPEC, NY). Itatim, 9.XI.1996, fl., E. Melo 1833 (HUEFS). Santa Terezinha, $12^{\circ} 51^{\prime} 13$ '"S, 39²8'33'W, 24.II.2000, fr., J.G. Jardim et al. 2859 (CEPEC, HUEFS, HUESC).

24. Erythroxylum santosii Plowman, Fieldiana, Bot. 19: 25. 1987.

Fig. 5d-f

Arbusto ca. 2 m alt., ramo castanho a castanho claro, lenticelas pouco numerosas, concentradas na porção jovem dos ramos. Catafilos do mesmo tamanho que as estípulas, pouco numerosos, distribuídos ao longo ramo, esparsos; Estípulas persistentes, 3-4 mm compr., largamente ovais, não estriadas, margem inteira, ápice arredondado, 2(-3)-setulado; pecíolo 2-3 mm compr. Lâmina foliar 4-9 × 2-3,5 cm, cartácea, oblonga, lanceolada, face adaxial castanha clara (quando herborizada), opaca, abaxial ocre (quando herborizada), base cuneada, margem plana, ápice agudo. Fascículo 1-3 flores, bractéolas 3, ca. 1,5 mm compr., lanceoladas, não estriadas, margem inteira. Flor com pedicelo de 1,5-2 mm compr.; cálice verde, lobos 1,5-2 × 0.7-1,1 mm., lanceolados, maiores que o tubo estaminal; pétalas amareladas, ca. $2,5 \times 1,5 \mathrm{~mm}$, oblongas; tubo estaminal ca. 1,5 mm compr., margem denticulada, ovário 1-1,2 mm compr., oblongo. Flor brevistila estames ca. 2,5 mm compr., estiletes ca. 1,7 mm compr., livres. Flor longistila não observada. Drupa não observada.

Esta espécie é conhecida apenas pelo holótipo proveniente de Teixeira de Freitas, localizada no extremo sul da Bahia. Pertence a Erythroxylum sect. Archerythroxylum, sendo próxima morfologicamente a E. ochranthum, mas pode diferenciada por suas lâminas foliares 

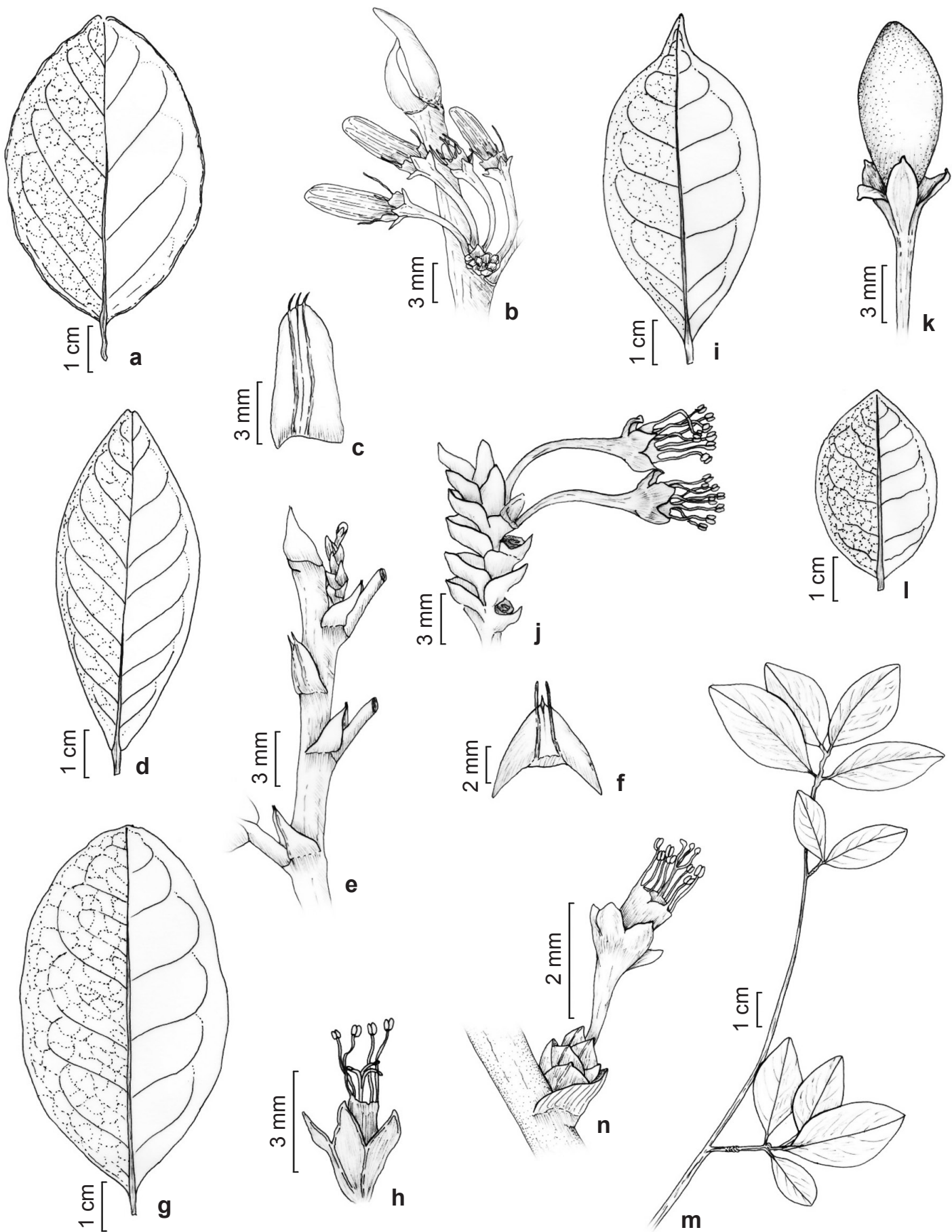

L $[\pi$
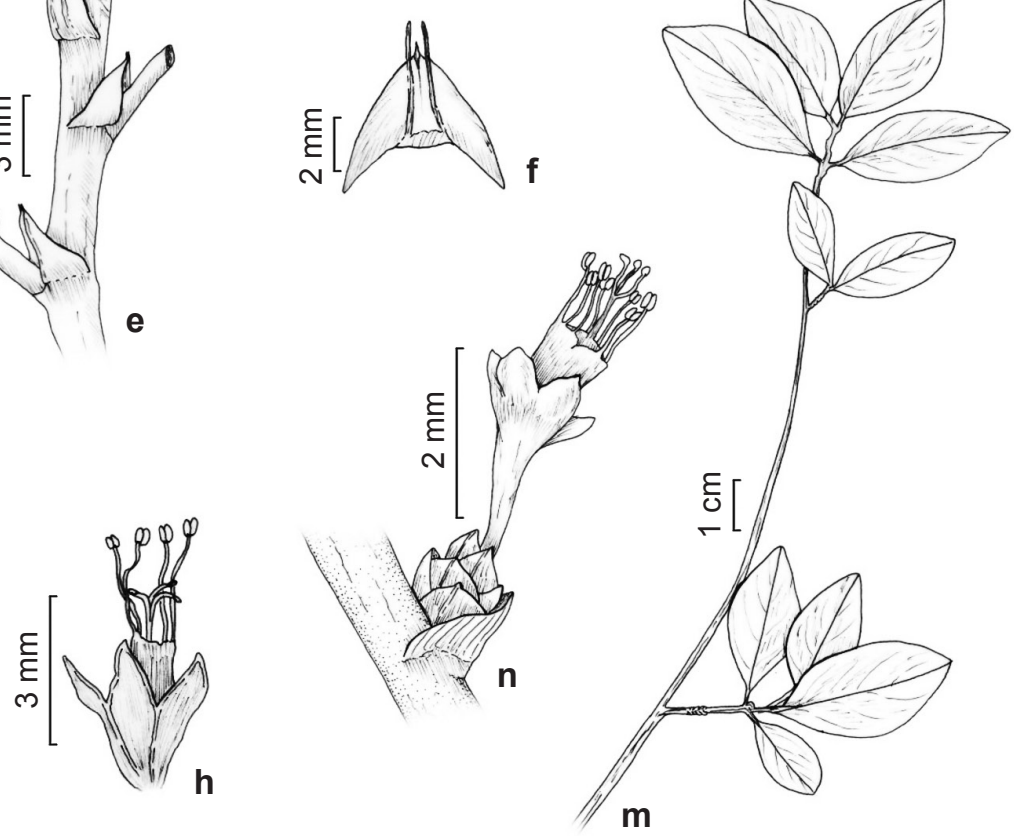

Figura 5 - a-c. Erythroxylum pulchrum - a. lâmina foliar; b. ápice do ramo com catafilos e drupas; c. estípula. d-f. E. santosii - d. lâmina foliar; e. ramo com catafilos e estípulas; f. estípula. g-h. E. splendidum - g. lâmina foliar; h. flor brevistila. i-j. E. squamatum - i. lâmina foliar; j. catafilos e flores longistilas. k-1. E. suberosum - k. drupa; 1. lâmina foliar. m-n. E. tenue - m. ramo; n. detalhe do ramo com catafilo, bractéolas espiraladas e flor longistila. Figure 5 - a-c. Erythroxylum pulchrum - a. leaf; B. twig apex with cataphylls and drupes; c. stipule. d-f. E. santosii - d. leaf; e. branch with cataphylls and stipules; f. stipule. g-h. E. splendidum - g. leaf; h. short-styled flower. i-j. E. squamatum - i. leaf; j. cataphylls and short-styled flowers. k-1. E. suberosum - k. drupe; 1. leaf. m-n. E. tenue - m. branch; n. detail of branch with cataphyll, spirally bracteoles and long-styled flower. 
oblongas ou lanceoladas (vs. elíptica a oboval em E. ochranthum), flores com pedicelo de 1,5-2 mm compr. e 3 bractéolas lanceoladas (vs. pedicelos de 4-10 em e 2 bractéolas oblongas em E. ochranthum) e tubo estaminal com margem denticulada (vs. margem crenulada em E. ochranthum).

Material examinado: BRASIL. BAHIA: Teixeira de Freitas, 12.V.1971, f1., T.S. Santos 1618 (CEPEC).

\section{Erythroxylum splendidum Plowman, Fieldiana,} Bot. 19: 25. 1987.

Fig. 5g-h

Arbusto ou arvoreta 1-7 m alt., ramo castanho a castanho escuro, lenticelas pouco numerosas, distribuídas por todo o ramo. Catafilos do mesmo tamanho que as estípulas, pouco numerosos, presentes em todo o ramo, esparsos; Estípulas persistentes, 1,5-2 mm compr., triangulares, não estriadas, margem inteira, ápice agudo, 2-setulado; pecíolo 2-13 mm compr. Lâmina foliar 4-15 $\times$ $3,5-5 \mathrm{~cm}$, coriácea, elíptica ou oval, face adaxial verde escura brilhante, abaxial verde clara brilhante, base cuneada, margem plana ou frequentemente ondulada, ápice arredondado ou agudo. Fascículo 1-8 flores, bractéolas 3, 1-1,3 mm compr., ovais a largamente ovais, não estriadas, margem inteira, às vezes erosa. Flor com pedicelo de 1-2 mm compr.; cálice verde, lobos 1,5-2,5 mm compr., triangulares ou ovais, maiores que o tubo estaminal; pétalas ocres, amareladas ou de coloração creme 3-4 $\times$ $1,3-1,8 \mathrm{~mm}$, oblongas; tubo estaminal $1-1,5 \mathrm{~mm}$ compr., margem inteira, ovário ca. 1,8 mm compr., elíptico. Flor brevistila: estames $2-3 \mathrm{~mm}$ compr., estiletes ca. 1,5 mm compr. conatos $1 / 2$ compr. Flor longistila: estames opositissépalos $1-1,5 \mathrm{~mm}$ compr., alternissépalos 2-2,5 mm compr; estiletes ca. $3 \mathrm{~mm}$ compr. conatos $1 / 3$ compr. Drupa 10-15 mm compr., falcada, endocarpo 3-sulcado.

A espécie tem registro apenas para a Bahia (Loiola 2013) e foi coletada em restinga arbustiva e arbórea. Pertence a Erythroxylum sect. Megalophyllum e apresenta similaridade morfológica com E. grandifolium, mas pode ser diferenciada pela coloração castanho a castanho escuro dos ramos (vs. esbranquiçada em $E$. grandifolium), pelas lâminas foliares com face abaxial brilhante (vs. opaca em E. grandifolium) e ápice arredondado ou agudo (vs. acuminado, às vezes cuspidado em $E$. grandifolium).

Material selecionado: BRASIL. BAHIA: Cairu, 29.IV.1980, fr., T.S. Santos et al. 3594 (CEPEC). Marau, 18.I.1967 fl. e fr., $R$ P. Belém \& R. S. Pinheiro 3170 (CEPEC). Itacaré, 30.I.1977, fl., R.M. Harley et al.

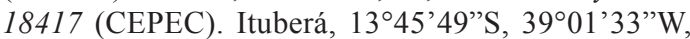

29.III.2013, fl. e fr., T. Araújo \& M. Nogueira 187 (CEPEC, HUEFS). Valença, 11.XII.1980, fr., L.A. Mattos Silva et al. 1262 (CEPEC, HRB, HUEFS, MBM, RB).

26. Erythroxylum squamatum Sw., Prod. 75. 1788.

Fig. $5 \mathrm{i}-\mathrm{j}$

Arbusto ou árvore 1-13 m alt., ramo castanhoacinzentado, porções jovens esverdeadas; lenticelas pouco numerosas, distribuídas por todo o ramo. Catafilos do mesmo tamanho que as estípulas, escamiformes, numerosos, presentes em todo o ramo, adensados na base de ramos novos ou ramos de crescimento curto, congestos e/ou esparsos; Estípulas persistentes, $2-3 \mathrm{~mm}$ compr., triangulares, estriadas (estrias evidentes apenas na face interna ou quando jovens), margem inteira, ápice agudo, 3-setulado; pecíolo 3-7 mm compr. Lâmina foliar 6-15 × 3-8 cm, coriácea, oblonga, elíptica, às vezes oboval, face adaxial verde escura, abaxial verde clara, opaca, base cuneada, margem plana, ápice acuminado ou cuspidado. Fascículo 1-30 flores, bractéolas 2, 1-2 mm compr., estreitamente triangulares, lisas, margem inteira. Flor com pedicelo de ca. $1 \mathrm{~cm}$ compr.; cálice verde, lobos $1,5-2 \times$ ca. $1 \mathrm{~mm}$, triangulares ou ovais, pouco maiores que o tubo estaminal; pétalas de coloração creme, ca. $4 \times 1,5 \mathrm{~mm}$, oblongas; tubo estaminal ca. 1,5 mm compr., margem crenulada, ovário 1,5-2 $\mathrm{mm}$ compr., oblongo. Flor brevistila: estames 3-4 $\mathrm{mm}$ compr., estiletes $2-2,5 \mathrm{~mm}$ compr., livres. Flor longistila: estames opositissépalos ca. 1,5 mm compr., alternissépalos ca. $2 \mathrm{~mm}$ compr; estiletes 3-4 mm compr., livres. Drupa 12-20 mm compr., oblonga, endocarpo 6-sulcado.

Erythroxylum squamatum possui ampla distribuição geográfica, ocorrendo nas Antilhas e América do Sul. No Brasil, está presente nas Regiões Centro-Oeste, Nordeste e Norte (Loiola 2013). Na Bahia desenvolve-se em floresta ombrófila densa de terras baixas podendo alcançar áreas submontanas. Pertence a Erythroxylum sect. Rhabdophyllum e pode ser reconhecida pelos catafilos escamiformes, estípulas inconspicuamente estriadas (estrias evidentes apenas na face interna ou quando jovens), pedicelos alongados (ca. $1 \mathrm{~cm}$ compr.) e drupas com endocarpo 6-sulcado.

Material selecionado: BRASIL. BAHIA: Almadina, 1444'11'S, 3941'57'W, 4.IV.1997, fl., W. Thomas et al. 11452 (CEPEC). Ipiaú, 26.X.1970, fl., T.S. Santos 1191 (CEPEC). Ituberá, 4.II.1983, est., T. Plowman \& A.M. de Carvalho 12813 (CEPEC). Una, 15.XI.1980, est., A. Rylands \& J.L. Hage 157 (CEPEC). 
27. Erythroxylum suberosum A. St.-Hil. Pl. usuel. bras., p.1. 1828.

Fig. $5 \mathrm{k}-1$

Arbusto 1-2,5 m alt., ramo castanho ou castanho acinzentado, lenticelas pouco numerosas, elípticas, distribuídas por todo o ramo. Catafilos do mesmo tamanho que as estípulas, numerosos, presentes por todo o ramo e/ou agrupadas nas porções jovens do mesmo, esparsos ou congestos na porção jovem do ramo; Estípulas persistentes, 2,5-3 mm compr., triangulares, estriadas, margem inteira, ápice arredondado, 3-setulado; pecíolo 2,5-3 mm compr. Lâmina foliar 4-7 × 2-4,4 cm, coriácea, elíptica, oval ou oboval, face adaxial verde escura brilhante, abaxial verde clara, opaca, base cuneada ou arredondada, margem plana, às vezes levemente revoluta, ápice arredondado. Fascículo 1-3 flores, bractéolas 3, 1-1,3 mm compr., ovais, não estriadas, margem inteira. Flor com pedicelo de 7-11 mm compr.; cálice verde, lobos 2-3 $\times 2-3 \mathrm{~mm}$, ovais, acuminados, maiores que o tubo estaminal; pétalas amareladas, alvas ou de coloração creme, 3-4 × 1,5-2 mm, oblongas; tubo estaminal ca. 1,2 $\mathrm{mm}$ compr., margem denticulada, ovário ca. $1 \mathrm{~mm}$ compr., oblongo. Flor brevistila: estames ca. $4 \mathrm{~mm}$ compr., estiletes ca. 1,3 mm compr. livres Flor longistila: estames opositissépalos ca. 1,5 mm compr., alternissépalos ca. 2,3 mm compr; estiletes 2,8-3,2 mm compr. livres. Drupa 6-10 mm compr., oblonga, endocarpo liso ou suavemente 6-sulcado.

Espécie de ampla distribuição geográfica com registros em todas as regiões do país e presente nos biomas da Amazônia, Caatinga, Cerrado e Mata Atlântica (Loiola 2013). Na Bahia é predominantemente encontrada no Cerrado e possui poucos registros na Mata Atlântica, sempre em restinga arbustiva. Pertence a Erythroxylum sect. Macrocalyx e pode ser reconhecida por sua lâmina foliar coriácea com ápice arredondado, pedicelo com 7-11 mm compr., lobos do cálice com ápice acuminado e maiores que o tubo estaminal. Material selecionado: BRASIL. BAHIA: Entre Rios, $12^{\circ} 18^{\prime} 42^{\prime}$ 'S, 37050'15"W, 17.VI.2001, fr., M.L. Guedes et al. 8983 (ALCB, CEPEC). Una, 4.XII.1991, fr., A.M. Amorim et al. 510 (CEPEC).

28. Erythroxylum tenue Plowman, Fieldiana, Bot., 19: 35. 1987.

Fig. $5 \mathrm{~m}-\mathrm{n}$

Arbusto 1-3 m alt., ramo castanho acinzentado, porções jovens esverdeadas; lenticelas pouco numerosas, distribuídas por todo o ramo. Catafilos do mesmo tamanho que as estípulas, pouco numerosos, presentes em todo o ramo, esparsos; Estípulas persistentes, 1-2 mm compr., triangulares, estriadas, margem inteira, ápice agudo, 3-setulado; pecíolo 3-5 mm compr. Lâmina foliar 2,5-7,5 × 1,3-3,6 cm, membranácea, elíptica ou oval, face adaxial verde escura, abaxial verde clara, opaca, base cuneada ou arredondada, margem plana, ápice agudo a acuminado. Fascículo 1-3(-5) flores, bractéolas 6 ou mais, , ,6-1 mm compr., espiraladas, ovais, estriadas, margem inteira. Flor com pedicelo de $2-5 \mathrm{~mm}$ compr.; cálice verde a ocre, lobos $0,4-0,6 \times$ ca. $0,5 \mathrm{~mm}$, triangulares, pouco menores que o tubo estaminal; pétalas de coloração creme, $1,2-2 \times 0,4-0,7 \mathrm{~mm}$, elípticas; tubo estaminal 1-2 $\mathrm{mm}$ compr., margem crenulada, ovário ca. $1 \mathrm{~mm}$ compr., oblongo. Flor brevistila: estames 1,2-1,7 mm compr., estiletes $1-1,4 \mathrm{~mm}$ compr., conatos $1 / 2$ compr. Flor longistila: estames opositissépalos ca. 0,7 mm compr., alternissépalos ca. $1 \mathrm{~mm}$ compr; estiletes ca. $1,5 \mathrm{~mm}$ compr., conatos $2 / 3$ compr. Drupa 7-10 mm compr., oblonga, endocarpo liso.

Erythroxylum tenue endêmico da Bahia (Loiola 2013) e ocorre principalmente em restinga, mas é encontrada também em mussununga, floresta de tabuleiros e no sub-bosque de floresta ombrófila densa de terras baixas. Pertence a Erythroxylum sect. Rhabdophyllum e pode ser reconhecida pelas bractéolas numerosas (6 ou mais), lobos do cálice frequentemente com coloração ocre, menores que o tubo estaminal e estiletes parcialmente conatos em ambos tipos florais.

Material selecionado: BRASIL. BAHIA: Acaraí, 1.I.1971, fl., T.S. Santos 1712 (CEPEC). Guaratinga, 29.III.1973, fl., R.S. Pinheiro 2046 (CEPEC). Ilhéus, $14^{\circ} 58^{\prime} 65^{\prime}$ 'S, 3902'10”'W, 6.XII.2006, f1., E.J. Lucas et al. 1075 (CEPEC). Itabuna, 30.XI.1970, f1., L.E. Mello Filho \& M. Emmerich 3022 (CEPEC). Maraú, 12.VI.1979, fl., S.A. Mori et al. 11965 (CEPEC). Prado, $17^{\circ} 05^{\prime} 09^{\prime}$ 'S, 39 $9^{\circ} 19^{\prime} 19^{\prime \prime} \mathrm{W}, 15 . \mathrm{III} .2013$, est., T. Araújo \& M. Nogueira 201 (CEPEC). Una, III.1987, fl., M. Sobral \& L.A. Mattos Silva 5497 (CEPEC).

\section{Agradecimentos}

Os autores agradecem à Coordenação de Aperfeiçoamento de Pessoal de Nível Superior (CAPES), a concessão de bolsa de mestrado ao primeiro autor; ao Conselho Nacional de Pesquisas e Desenvolvimento (CNPq), o financiamento deste trabalho através do Edital REFLORA Processo $563548 / 2010-0$ e a bolsa de produtividade em pesquisa concedida ao ultimo autor (Processo 306992/2012-4); à UEFS e CEPEC, a infraestrutura disponibilizada, e a Lucas Marinho, as ilustrações. 


\section{Referências}

Amorim, A.M.A.; Thomas, W.W.; Carvalho, A.M.V. \& Jardim, J.G. 2008. Floristics of the Una Biological Reserve, Bahia, Brasil. Memoirs of the New York Botanical Garden 100: 67-146.

Brasil. Ministério do Meio Ambiente. 2008. Instrução Normativa $\mathrm{n}^{\circ} 6$, de 23 de setembro de 2008. Diário Oficial, Brasília, DF, v. 145, n. 185, Seção 1, 75-83.

Cronquist, A. 1981. An integrated system of classification of flowereing plants. Columbia University Press, New York. 1261p.

Costa-Lima, J.L. \& Alves, M. 2013. A new species of Erythroxylum (Erythroxylaceae) from the Brazilian Atlantic Forest. Phytotaxa 141: 55-60.

Daly, D. 2004. Erythroxylaceae. In: Smith, N.; Mori, S.A.; Henderson A.; Stevenson, D.W. \& Heald, S.V. Flowering plants of the Neotropics. Princeton University Press, Princeton. Pp. 143-145.

Heywood, V.H.; Brummit, R.K.; Culham, A. \& Seberg, O. 2007. Flowering plants familes of the world. Firefly Books, Ontario. 424p.

IBGE - Instituto Brasileiro de Geografia e Estatística. 2004. Mapa de Biomas do Brasil. Disponível em <ftp://ftp.ibge.gov.br/CartaseMapas/ MapasMurais/>. Acesso em 14 julho 2013.

Loiola, M.I.B. 2001. Revisão taxonômica de Erythroxylum P.Browne sect. Rhabhophyllum O.E. Schulz (Erythroxylaceae Kunth). Tese de Doutorado. Universidade Federal Rural de Pernambuco, Recife. 238p.

Loiola, M.I.B. 2013. Erythroxylaceae. In: Lista de espécies da flora do Brasil. Jardim Botânico do Rio de Janeiro. Disponível em <http://floradobrasil.jbrj. gov.br/2011/FB007680>. Acesso em 27 agosto 2013.

Loiola, M.I.B. \& Sales, M.F. 2008. Two new species of Erythroxylum sect. Rhabdophyllum (Erythroxylaceae) from north-eastern Brazil. Kew Bulletin 63: 655-659.

Loiola, M.I.B. \& Sales, M.F. 2012. Erythroxylum ayrtonianum (Erythroxylaceae): a new species from Brazil. Novon 22: 48-50.

Plowman, T. 1983. New species of Erythroxylum from Brazil and Venezuela. Botanical Museum Leaflets 29: 273-290.
Plowman, T. 1984. New taxa of Erythroxylum (Erythroxylaceae) from the Amazon Basin. Acta Amazonica 14: 117-177.

Plowman, T. 1986. Four news species of Erythroxylum (Erythroxylaceae) from Northeastern Brazil. Brittonia 38: 189-200.

Plowman, T. 1987. Ten new species of Erythroxylum (Erythroxylaceae) from Bahia, Brazil. Fieldiana Botany 19: 1-41.

Plowman, T. \& Hensold, N. 2004. Names, types and distribution of neotropical species of Erythroxylum (Erythroxylaceae). Brittonia 56: 1-53.

Radford, A.E.; Dickison, W.C.; Massey, J.R. \& Bell, C.R. 1974.Vascular plant systematics. Harper \& Row, New York. 891p.

Schulz, O.E. 1907. Erythroxylaceae. In: Engler, A. (ed.). Das Pflanzenreich. Vol. 4. Pp. 1-176.

Schulz, O.E. 1933. Zwei neue Erythroxylum Arten aus Amerika. In: Notizblatt des Botanischen Gartens und Museums zu Berlin. Dahlem, Berlin. Vol. 11. Pp. 722-723.

Thiers, B. [continuously updated]. Index herbariorum: a global directory of public herbaria and associated staff. New York Botanical Garden's Virtual Herbarium. Disponível em $<$ http:// sweetgum.nybg.org/ih/>. Acesso em 4 fevereiro 2013.

Thomas, W.W. \& Barbosa, M.R.V. 2008. Natural vegetation types in the Atlantic coastal forest of northeastern Brazil. Memoirs of the New York Botanical Garden 100: 6-20.

Xi, Z.; Ruhfel, B.R.; Schaefer, H.; Amorim, A.M.; Sugumaran, M.; Wurdack, K.J.; Endress, P.K.; Matthews, M.; Stevens, P.F.; Mathews, S. \& Davis, C.C. 2012. Phylogenomics and a posteriori data partitioning resolve the Cretaceous angiosperm radiation in Malpighiales. Proceedings of the National Academy of Sciences of the United States of America 109: 17519-17524.

Wurdack, K.J. \& Davis C.C. 2009. Malpighiales Phylogenetics: gaining ground on one of the most recalcitrant clades in the angiosperm tree of life. American Journal of Botany 96: 1551-1570. 